\title{
Dealing with Parallel Universes: Antinomies of Sovereignty and the Protection of National Identity in European Judicial Discourse
}

\author{
Theodore Konstadinides* \\ University of Surrey
}

\begin{abstract}
This article addresses the relevance of national identity to EU and domestic judicial practice. It argues that there are two parallel universes of protection in the EU Treaty and national constitutions which often pose conflicting obligations to those bound by them and which do not communicate nearly enough. Judicial interpretation of the relevant EU and national provisions is a welcome development but not always key to reconciling differences. To this purpose, the article reflects on the CJEU's interpretation of the EU's renewed commitment in the Lisbon Treaty to protect national identities. It also provides a comparative overview of how Member States have construed their own national identity. The latter involves making connections with current issues emerging from post-Lisbon domestic case law that this article contributes to and advances. As it is illustrated, the respect for national identity afforded by the Treaty is amorphous and often fails to capture the level of protection mandated by national constitutions. At the same time, national constitutions provide a fuzzy picture with different levels of commitment to identity. The way these two constitutional charters ${ }^{1}$ have been interpreted by European and certain national judges will help us identify the different approaches and illustrate the conflict between them vis-à-vis the concept of an EU federalised structure. Ultimately, the article aims to create a typology of situations where identity retention should be reserved to Member States with a view to resolving the current tension between the two legal orders. It will point to the possibility for a plurality of 'limited powers' approach acting as a check on the EU, while avoiding the risk of jeopardising the course of European integration.
\end{abstract}

\footnotetext{
* Senior Lecturer in Law, University of Surrey. This work has been kindly supported by the European Central Bank (ECB) Legal Research Programme. The views expressed therein are solely those of the author and not the ECB or the Eurosystem. I would like to thank Maria Ioannidou and colleagues from the City Law School (where this research was presented in draft form) for their useful comments. All mistakes are mine only.

${ }^{1}$ The CJEU affirmed that the Treaty is the Constitutional Charter of the then EC in Case 294/83 Le Verts [1986] ECR 1339.
} 


\section{INTRODUCTION}

The role of national constitutions as the utmost expression of sovereignty has been an overlying theme of European integration with respect to setting the conditions for the interaction between the national and European legal orders. After all, every Member State joined on the basis of its national constitution, either on the grounds of general provisions regarding membership in international obligations, or on the grounds of specific provisions specifically enacted to prepare the national legal order for EU accession. As such in the event of further competence transfer to the EU or conflict between EU and national law, national authorities are constitutionally obliged to look into the conditions their constitutions set out vis-à-vis their course of action. In this context, national reservations over the unconditional prevalence of EU law in the Member States have recently been expressed through emphasis of the highest national courts on national identity retention - i.e. keeping EU expansionist claims at bay by protecting constitutional premises which are intimate to the Member States' own identity.

Indeed, the concept of national identity has become en vogue since the coming into force of the Treaty of Lisbon. On the one hand, EU constitutional scholars have spent considerable time and effort trying to decipher the true intentions of the relevant Treaty provision (Article 4 (2) TEU) underpinning it. ${ }^{2}$ On the other hand, national judges have not exactly relished the chance to make use of it because the protection afforded to identity in their national constitutions (constitutional identity) is often different and more intense to that envisaged by the Treaty (as interpreted by the CJEU). This article is about the antinomies between the EU and the Member States with regard to national identity protection as expressed in the relevant judicial discourse and how to resolve them.

The article commences in section II by providing some background on the semantics of national against constitutional identity. It then looks into the Treaty's commitment to respect national identity in light of the broader priorities in European integration. It moves on into section III to explore national identity from the perspective of CJEU case law and demonstrate how the Luxembourg Court has balanced the concept of

\footnotetext{
${ }^{2}$ For instance the emphasis is often on the history and dual function of Article 4 (2) TEU (the so-called identity clause) which can be equally construed to derogate from EU legislation as well as challenge judicially its constitutionality. See: B.Guastaferro 'Beyond the Exceptionalism of Constitutional Conflicts: The Ordinary Functions of the Identity Clause' Jean Monnet Working Paper 01/12; A.Von Bogdandy, S.Schill 'Overcoming Absolute Primacy: Respect for National Identity under the Lisbon Treaty' (2011) 48 CMLR 1417; L.Besselink 'National and constitutional identity before and after Lisbon' (2010) 3(6) Utrecht Law Review 36
} 
national identity against other rights and freedoms conferred by EU law. In section IV, the article introduces the concept of constitutional identity as it has been developed in the law of the Member States and has been upheld by certain domestic courts. Ultimately a lapse of communication is revealed between the two approaches and suggestions are made about finding ways to re-establish it.

The article identifies key trends in the level of protection mandated by national courts in order to explore further the relevance of national identity as a power restraint tool against the transfer of sovereign powers to the EU. Particular emphasis is placed on the German paradigm which although cannot claim a monopoly of creation of identity review, it is perhaps the most robust example of identity retention in terms of demonstrating that constitutional court judges are sometimes willing to go to excruciating lengths to defend the constitutional integrity of their legal system against 'outsider' threats. Having said that, it is important to note from the outset that judicial exposition on the matter of identity currently remains theoretical in the Member States and has, therefore, not stabilised the role of unilateral 'identity review' by national courts as a new basis for challenging EU law.

In search for a typology of cases where identity retention as envisaged by Member States is vital for the preservation of their constitutional integrity (especially with reference to the ratification of EU Treaties or transposition of secondary legislation), we will also look into other national courts, namely in France and the UK. As these courts have explicitly addressed their identity concerns, we will observe how they have protected constitutional identity and whether their review carries the same intensity as that undertaken by their German counterparts. This will help us to make a case about the inter-judicial effects of identity review.

The choice of certain Member States as focal points is not merely because they may be involved in shaping policies across a much wider range than their European counterparts. More important, the courts under study are amongst those that have taken lead in expressly invoking ideas relevant to constitutional identity retention. Thus, the case studies below provide sufficient evidence to allow for conclusions to be drawn vis-à-vis observing trends in the use of constitutional identity by the majority of national courts in the Member States.

\section{SETTING UP THE SCENE}

\section{A. National versus Constitutional Identity: A note on semantics}

The focus of this article on the judicial practice pertaining to the concept of national identity can assist both the Member States' authorities and the EU Institutions at the vertical level to put their constitutional limits into perspective and measure the legal 
significance of respect to national identity. Yet, in order to do so, it is important to determine whether, 'constitutional identity' is stated to be different from the 'national identity' referred to in Article 4 (2) TEU.

Most of the relevant literature on the identity clause seems to use the terms 'national identity' and 'constitutional identity' interchangeably. Does it really matter? Is it a matter of semantics? Let us distinguish between these two perceptions of national identity. Simply put, national identity is entrenched in the identity of the citizenry which is subject to the Constitution and constitutional identity is inherent in esoteric values and principles encapsulated and safeguarded in the Constitution.

National identity can be contextualised by reference to the conventional account of 'We the People' as constituent power. The idea behind national identity as the identity of the citizenry-subject to the constitution is founded on the claim that national constitutions gain their mandate from the people who set them up and give them authority. Besides, national identity pre-dates the Constitution. As such, timing is important because it differentiates national identity from the post-national notion of constitutional identity examined below. Accordingly, the Constitution is conceived to be subject to amendment or, under certain circumstances, abrogation by the same people (demos) who, more often than not, share distinctive national features - a collective identity of sorts based on language, common heritage etc (Volksidentität). Hence, it can be argued with some certainty that national and constitutional identity are often intertwined because the values enshrined in a Constitution are entrenched with the identity of the demos.

Hence, constitutional identity or the identity of the constitution encompasses national identity as it features in constitutional law. It consists of an element of national identity and it resides in sources or assets internal to the codified and principled constitutional narrative of national constitutions endowing them with substance. It is in this regard that constitutional identity (and not the more generic and allencompassing concept of national identity) has often been invoked by national courts as a free-standing principle protected under Article 4 (2) TEU in the form of (to use the language of the provision under study) 'fundamental constitutional structures' - a very broad notion indeed. Nonetheless, the Treaty's identity clause seems to be providing a means of protecting the fundamental interests which defending Member States may resort to against the otherwise tidal force of EU law. The purpose behind it is to safeguard diversity and preserve certain national competences that remain dear to the Member States.

Having said that, 'constitutional identity' is stated to be different from the 'national identity' referred to in the broadly drafted provision of Article 4 (2) TEU. Hence we are left with two parallel universes of protection - something which makes this study 
pertinent for future judicial practice. What is more important for the purpose of the discussion is that the CJEU's interpretation of Article 4 (2) TEU seems to be undermining constitutional identity. While, therefore, Member States appeared willing (at least shortly after the ratification of the Lisbon Treaty) to communicate to the CJEU what constitutes an aspect of their identity by making use of the preliminary reference procedure, the CJEU's established that national identity as protected by Article 4 (2) TEU is a rather limited concept. It neither constitutes a catch-all tool to limit the transfer of sovereign powers to the EU nor is an exception to the principle of EU law primacy.

In a number of recent cases on Article 4 (2) TEU, Luxembourg judges have stressed to their counterparts in the Member States that identity does not enjoy a higher status than, for instance, public policy interests do. Instead, national identity is bound to be balanced by a CJEU rigid proportionality assessment against other legal interests relevant to the advancement of European integration. This is generally an accepted state of affairs in most Member States although certain national courts have protested that matters are not that simple. Almost as a counter-measure, they have abstained from making use of Article 4 (2) TEU as a channel to communicate to the CJEU what constitutes part of their identity. They have rather adopted an internal constitutional approach to the relationship between the national and EU legal order premised on the view that domestic constitutional provisions provide a different approach to national identity protection than that which is intended by the Treaty. This inwards approach to constitutional identity comprises various areas of national policy and necessitates specific in-depth study.

Thus, even if the intention of the Treaty drafter was to bring national identity into the primary law equation and - in light of the ever expanding EU competences - recognise it expressly as a manifestation of national sovereignty, the result has been somewhat disappointing in enhancing communication between European and national courts about the latter's status of constitutional identity. As European and domestic case law advances we are witnessing a gradually widening schism between respect for national identity under Article 4 (2) TEU and the protection of national identity under the provisions of national constitutions. To provide an example, against the CJEU's reasonings on Article 4 (2) TEU, the Constitutional Court of Germany (BVerfG), in its role as the protector of constitutionality against potential transgressions of powers by the EU Institutions, relishes every opportunity to stress ominously that national identity may not be balanced against any other legal interests.

Taking the above disparity of identity protection between European and domestic legal orders into consideration, this article rotates around two interpretations of national identity in judicial politics which are manifest in other areas of application of EU law where there is potential for conflict - an 'integrationist' one which is 
predominant in the case law of the CJEU and an 'insular' one driven by national prerogative illustrated by some national courts. Obviously the opposition between an integrative approach by the CJEU and an insular approach by certain national courts is hardly new or surprising in theoretical analyses justifying the primacy of EU law. As such, this contribution aims to reach beyond a discussion of the theoretical contours of national identity as a means of reviving the EU law primacy discourse. It will observe whether and how the CJEU and national courts are balancing national identity against various aspects of European integration. It is important, for instance, to observe the potential for mutual influence and dialogue of national courts at the horizontal level and the role of express comparative reasoning by these courts in this context.

\section{B. Respect for National Identity in the Treaty and Broader Priorities in European Integration}

Let us take things from the beginning. The EU is under an obligation to respect the identities of the Member States - political or constitutional. The Treaty makes this obligation explicit. A 'national identity clause' was first inserted in the Treaty of Maastricht. Article F (1) TEU was the first provision to constitutionalise such obligation by plainly stressing that 'the Union shall respect the national identities of its Member States'. The periodic Treaty revisions merely renumbered this provision. Article F (1) TEU of the Maastricht Treaty was first replaced by Article 6 (3) TEU of the Amsterdam Treaty which in turn gave way to current Article 4 (2) TEU of the Lisbon Treaty. ${ }^{3}$ Not only is the latter provision a lot more comprehensive, compared to its predecessors, but it also encompasses binding obligations on the EU Institutions, as well as enforceable rights for the benefit of Member States.

Furthermore, Article 4 (2) TEU is longer and more descriptive than its predecessors and it is also supported by the preamble to the EU Charter of Fundamental Rights (the Charter) which reinforces that in its action, the EU respects the national identities of the Member States. ${ }^{4}$ What is more, the legal geography of Article 4 (2) TEU is remarkable. Respect for national identity is part of the Article 4 TEU package including the traditional constitutional/procedural principles of conferral and loyalty.

\footnotetext{
${ }^{3}$ The origins of Article 4 (2) TEU lie firmly in Article I-5 of the ill-fated EU Constitutional Treaty which set out to clarify the perplexity of EU competences. See for detail on the European Convention's mandate with reference to complementary competences, including the identity clause: B. Guastaferro, 'Beyond the Exceptionalism of Constitutional Conflicts: The Ordinary Functions of the Identity Clause' (2012) Jean Monnet Working Paper 01/12, 13 onwards.

4 'The Union contributes to the preservation and to the development of these common values [the indivisible, universal values of human dignity, freedom, equality and solidarity; [and]... the principles of democracy and the rule of law] while respecting the diversity of the cultures and traditions of the peoples of Europe as well as the national identities of the Member States and the organisation of their public authorities at national, regional and local levels...'
} 
Respect for all three principles is therefore fundamental to the good functioning of the EU. But respect by whom? The legislature in the exercise of its functions, the European Council in its executive capacity, or the CJEU in the exercise of its judicial functions? And if Article 4 (2) TEU binds all EU actors, does it bind some EU Institutions more than others?

The first thing that comes to mind when reading Article 4 (2) TEU is that as a complement to the principles enshrined in the proximate Article 5 TEU (i.e. conferral, subsidiarity and proportionality), it is primarily addressed to the EU legislature, meaning that the Commission, the Council and the European Parliament are not to pursue objectives which may impinge upon the national identity of the Member States. Moreover, Article 4 (2) TEU also seems to have the implied capacity to restrain the EU legislature from pursuing objectives, which may be compliant with national identities but the manner in which they are pursued may jeopardise national identities. Although important to the quality of EU legislation, nothing in the wording of Article 4 (2) TEU suggests that its application is limited to the conduct of the EU legislature. The identity clause implies that the obligations stemming from the national identity clause are binding on the EU as a whole. This all-encompassing reference provides that all EU Institutions are bound (or, to be more precise, shall be bound) by Article 4 (2) TEU in the exercise of their duties.

One could also extend this obligation to the Member States' governments - they shall also respect the identities of their counterparts. For instance, national identity was an implicit, but nonetheless, determining factor in the diplomatic incident that occurred between Hungary and Slovakia in 2009, when the Slovak authorities refused the Hungarian President entry into Slovakia. ${ }^{5}$ More explicitly, it can be argued that the way a Member State construes its own identity can constitute a limit on another Member State's national identity. In that respect, a limitation to the operations of an EU mechanism by one Member State may violate the national identity of another Member State. For instance the EU emergency assistance facilities, such as the balance-of-payments facility, which operates under Art 143 TFEU, may be affected by the strictures of Art 4 (2) TEU. ${ }^{6}$

Hence, the Lisbon Treaty notes in Article 4 (2) TEU that it is mandatory for EU legislation to be compatible with the national identities of the Member States. By stretching the protection of national identity in Article 6 (3) TEU of the Amsterdam Treaty to include in Lisbon 'fundamental structures' and 'essential state functions', the Treaty drafters can be seen as attempting but nonetheless missing the opportunity to

\footnotetext{
${ }^{5}$ Case C-364/10 Hungary v Slovakia [2012] ECR I-0000.

${ }^{6}$ The aim of the balance-of-payments facility is to provide financial assistance to non-euro states experiencing difficulties with their balance of payments or movement of capital.
} 
forge a negative list of areas which are intimate to national sovereignty. One may hypothesise about what Member States could have achieved in Article 4 (2) TEU: an exclusive list of national competences comparable to that found in Article 3 TFEU which provides a catalogue of the EU's exclusive competences. Although such an analysis is appealing, as it will arise from the CJEU's interpretation of the provision, Article 4 (2) TEU is not drafted as a clause to regulate competence allocation but more as an abstract commitment which in most cases invites the EU legislature to exercise a degree of self-restraint regarding the exercise of its powers but lacking concrete guidelines.

In our attempt to understand Article 4 (2) TEU, it could be useful to place emphasis upon the language used by the drafter: 'The Union shall respect the equality of Member States before the Treaties as well as their national identities'. In this context, 'shall' appears to be mandatory and does not bear other meanings, for instance, as a synonym of the more permissive 'may'. Nonetheless, 'shall' is defined by its context and this is where the miscommunication between the CJEU and national courts arises. For instance, despite the mandatory tone of the Treaty in Article 4 (2) TEU, the CJEU has taken the view that national identity claims may not always be taken into account by the EU Institutions in the exercise of their competences.

The idea behind the CJEU's approach is that the EU's intention to respect the Member States' national identities has to be counterbalanced against the EU's mandate to promote integration. Besides, under Article 49 TEU, a state's accession to the EU presupposes the adaptation of national constitutions for membership. As a commentator has explained, 'the new Member State integrates its commitment and loyalty to the integration process in its identity and assumes the whole constitutional patrimony of the EU, including principles capable of profoundly modifying its national constitution. ${ }^{7}$ Against this idea, we can take an opposite view claiming that the preservation of national identity is essential to the polity. Since, as discussed earlier, identity pre-exists national constitutions, any constitutional modification mandated by EU membership does not imply an identity surrender or replacement with a European one. No transfer of powers can take place to an extent that Member States can no longer be considered independent states.

The CJEU has suggested that both obligations of commitment and loyalty which are required from Member States at the point of entry to the EU continue to exist following their accession. In this respect, national identity has to be considered against a working European (or to put it more accurately) EU identity. Lets us now

\footnotetext{
${ }^{7}$ R. Bustos Gisbert, 'National Constitutional Identity in European Constitutionalism' in A. Saiz Arnaiz and C. Alcoberro Llivina (eds.) National Constitutional Identity and European Integration (Cambridge, Intersentia, 2013), 88.
} 
attempt to rationalise the CJEU's inner logic. For the purpose of this contribution, the much-contested concept of 'European identity' is not taken to be synonymous with an 'EU-isation' movement which promotes the degradation of national identities. It is rather related to an incremental and voluntary adaptation, occurring through the Member States' adherence to an agreed set of values and objectives which have been developed, over time, by EU Institutions.

Values and objectives, such as economic and social cohesion and solidarity among the Member States are listed in the Treaty (Articles 2 and 3 TEU) and have effectively been guaranteed and expanded by Treaty revisions, EU law-making and the CJEU's jurisprudence. These values are shared by all Member States, as they are required to be acting together to promote stability and prosperity and to resolve political and economic crises in Europe.

A workable EU identity, as referred to in this contribution, is therefore not about promoting the denationalisation of Europe but it is built upon a common awareness of the purpose of the EU's integrative project. It is both dynamic and procedural in nature and it involves distinct structures of governance which mandate domestic adaptation. Traditional national identities are not marginalised as a result of this adaptation process - they merely co-exist within a broader setting that includes a European identity interacting with the national identity. As such, the anticipation of the existence of an EU identity can be considered as a major step forward in our understanding of the future of the EU constitutional project, and the role of national identities in placing limits on it. ${ }^{8}$

Seen in the above light, one can partially empathise with the CJEU's inner logic. The anticipation of the existence of an EU identity, however, is easier said than done since, as we will discuss later, according to certain national courts, the ratification of a new EU Treaty is conditional upon not introducing serious changes to the procedural and organisational set up of EU Institutions - at least not to such an extent that the Treaty will alter 'the identity of the EU'. For instance, the Danish Supreme Court seems to have reserved for itself the role of the final arbiter when it comes to monitoring the changes made to the EU by a new Treaty (e.g. the Treaty of Lisbon). It has to ensure that any such changes are not fundamental to the point that the EU has in effect assumed 'a new identity'.

\footnotetext{
${ }^{8}$ See more on European Identity from an EU institutional perspective: Copenhagen Europeam Summit of 14-15 December 1973, 'Declaration on European Identity', Bulletin of the European Communities 1973, No 12, p118-122; European Commission, 'The Development of European Identity', 2012. Available at <http://ec.europa.eu/research/social-sciences/pdf/development-of-european-identityidentities_en.pdf>

${ }^{9}$ Danish Supreme Court's decision on the constitutionality of Denmark's ratification of the Lisbon Treaty, Danish Supreme Court, Case 199/2012, Decision of 20 February 2013. A similar approach was
} 
Where does that leave us? As the case law reveals we are dealing with the conflict between two rights. Whilst we can empathise with national courts' protectionism of what is essentially their own - we cannot dismiss the CJEU judges' plea to their counterparts to look at the bigger picture. Let us now look at how the CJEU resolves identity claims before we move on to consider the approach of national courts.

\section{PROTECTION OF IDENTITY BY THE CJEU}

\section{A. National identity in EU judicial practice}

So far, the Treaty obligation imposed upon the EU to show respect to national identity has featured in a number of domestic cases involving disputes between individual citizens and Member States. We can distinguish between two types of cases which may be referred to the CJEU as concerning an aspect of national identity and therefore falling within the scope of Article 4 (2) TEU.

First, one comes across situations which concern fundamental constitutional values presented by national courts as part of national identity that may be common to the Member States (and the EU). ${ }^{10}$ These are cases that may arise from litigation in all Member States indistinctly challenging (to use a hypothetical example) the application of a Directive which endangers the right to privacy, protected both by national and EU law. When they reach the CJEU, these cases are only resolved in favour of Member States following a successful proportionality assessment which seeks to balance competing objectives and principles (i.e. that limitations on the right to privacy are justified in order to meet the generally recognised objective of preventing terrorism). ${ }^{11}$

Second, there are cases on constitutional provisions which may for instance take the form of a language requirement applied to all professionals - e.g. that all teachers in Irish state colleges are proficient in the Irish language. Such a requirement may be presented by national judges as means to preserve Irish national identity. As with the first category above, these cases may arise from litigation in all Member States and

also adopted in the past in Ireland. See Supreme Court of Ireland, Crotty v. An Taoiseach [1987] I.R. $713,783$.

${ }^{10}$ Here we refer to essential values pertaining to constitutional identity including for instance respect for democracy, the rule of law and fundamental rights. Not only these values are common to the Member States but they are equally respected by the EU via Article 2 TEU.

${ }^{11}$ Although not decided on identity as such, the CJEU held in Joined Cases C-293/12 and C-594/12 Digital Rights Ireland and Seitlinger and Others [2014] ECR-0000 resulting from Irish and Austrian preliminary references that by adopting the Data Retention Directive, the EU legislature exceeded the limits imposed by compliance with the principle of proportionality. It, therefore, declared it to be invalid. 
when they are referred to the CJEU, they are again subjected to a proportionality assessment (i.e. that a language proficiency requirement is necessary because it meets the objective of protecting and promoting a language which is both the national and first official language). ${ }^{12}$

As the above examples suggest, reference to identity appears to offer complementary protection to what pre-Lisbon (and even post-Lisbon) would have constituted cases argued on fundamental rights protection (in the first example) or public policy (in the latter). Nonetheless since the revision of Article 4 (2) TEU, a number of domestic courts seem to have preferred to rely on identity. This trend is manifest in disputes where a national rule makes it bureaucratically difficult or impossible for an individual to exercise a freedom under the Treaty (namely the freedom to move, reside freely and exercise a profession). In such cases, EU law has traditionally been implicated both by reference to the scope of the fundamental freedom in question and the permissible degree of deviation from that fundamental freedom. Also in such cases national courts will, more often than not, resort to the preliminary reference procedure using Article 4 (2) TEU as a derogation from their Member State's obligations under EU law. ${ }^{13}$

A national court can claim, for instance, that a Member State's transposition of a piece of EU legislation into national law conflicts with legitimate interests or principles which are deeply entrenched in its constitution. These may range from diversity and transparency and equal treatment between tenderers to nationality conditions for access to particular professions. In this fashion, Article 4 (2) TEU provides Member States with an express EU law derogation over the preservation of their national identity. Although innovative at first glance, the use of Article 4 (2) TEU as a justified restriction to the application of EU law does not revolutionise current CJEU practice on express Treaty derogations from EU fundamental freedoms under Articles 36, 45 (paras 3 and 4), 45, 62 and 65 TFEU.

The above derogations which broadly refer to public policy, public security, and public health, have been interpreted very narrowly by the CJEU. Likewise, national peculiarities that fall within the list of Article 4 (2) TEU (e.g. maintenance of law and order, safeguarding national security) and are, therefore, intimate to a Member State's identity have already been treated by the CJEU in the same way. It is also unlikely

\footnotetext{
${ }^{12}$ See for instance Case 379/87 Groener [1989] ECR 3967. Again a case that in the post-Lisbon constellation can be fought on identity grounds.

${ }^{13}$ See for detail T. Konstadinides 'Constitutional Identity as a Shield and as a Sword: The European Legal Order within the Framework of National Constitutional Settlement' (2011) 13 Cambridge Yearbook of European Legal Studies 195.
} 
that Member States would be granted a margin of appreciation to use national identity to advance another ground of defence.

As early as 1996 (the same time that the national identity clause of Article F (1) TEU was introduced in the Treaty of Maastricht) the CJEU explained that the protection of national identity cannot justify the exclusion of nationals of other Member States from all the posts in an area such as education (primary school teachers) unless these involve direct or indirect participation in the exercise of powers conferred by public law. ${ }^{14}$ No mention was made to Article F (1) TEU or national identity. The message arising from the CJEU's decision is that the obligations of Member States under EU law cannot be shaken by considerations relating to the preservation of national identity. This is out of respect for the constitutional value of the internal market freedoms or the protection of individual citizens who benefit from market access.

Nonetheless, it seems that national courts have developed new defences outside the scope of those explicitly mentioned in Article 4 (2) TEU (e.g. prohibition on titles of nobility in the state constitution). ${ }^{15}$ Weatherill argues that 'Article 4 (2) TEU is the door through which concerns to protect national identity enter free movement law, softening its sharp deregulatory edge. ${ }^{16}$ Although this appears to be true, we need to recall that since the identity clause cannot entail a full surrender of the internal market to domestic constitutional provisions, the case law on Article 4 (2) TEU has been informed by the pre-Lisbon (and, therefore, pre-Article 4 (2) TEU) free movement case law of the CJEU on balancing legitimate interests which are not expressly protected by the Treaty. ${ }^{17}$ In other words, national identity has indeed entered free movement law but likewise the rules that regulate free movement law have penetrated national identity. In this regard national rules may be treated as overriding reasons of general interest. We will discuss hereafter in light of the relevant case law whether this is a good or bad development for the safeguarding of national competences.

Genuine concerns of public interest have traditionally been recognised by the CJEU as permissible derogations from EU law. They include the mandatory requirements introduced by the CJEU in Cassis De Dijon, ${ }^{18}$ environmental protection ${ }^{19}$ and social

\footnotetext{
${ }^{14}$ C-473/93 Commission v Luxembourg [1996] ECR I-320.

${ }^{15}$ Case C-208/09 Sayn-Wittgenstein [2010] ECR I-13693 discussed in more detail below.

${ }^{16}$ S. Weatherill 'Free Movement of Goods' (2012) 61 (2) International \& Comparative Law Quarterly 541,546

${ }^{17}$ T. Konstadinides 'Constitutional Identity as a Shield and as a Sword: The European Legal Order within the Framework of National Constitutional Settlement' (2011) 13 Cambridge Yearbook of European Legal Studies 195.

${ }^{18}$ Case 120/78 Rewe-Zentral AG [1979] ECR 649.

${ }^{19}$ Case C-309/02 Radlberger [2004] ECR I-11763.
} 
protection $^{20}$ to name but a few. Legitimate interests also include the protection of fundamental rights stemming singularly from national constitutions. The latter interests are more closely linked to the Member States constitutional identity features that have been defended post-Lisbon under Article 4 (2) TEU. Additionally, as Maduro commented, 'the preservation of national constitutional identity can also enable a Member State to develop, within certain limits, its own definition of a legitimate interest...,21

So what happens in practice when a case on national identity is raised before the CJEU and how willing are the judges in Luxembourg to entertain questions of national identity? The CJEU agreed in Sayn-Wittgenstein that equality between citizens and the abolition of privilege forms part of national identity according to Article 4 (2) TEU and can be utilised as a justification for prohibiting the acquisition of noble titles. ${ }^{22}$ Similarly, in Malgožata Runevič-Vardyn ${ }^{23}$ regarding rules on identity cards and passports, the CJEU established that the Lithuanian language constitutes 'a constitutional asset which preserves the nation's identity.' ${ }^{24}$ This 'asset' is further protected by the Charter in the form of respect to cultural and linguistic diversity under Articles 3 (3) and 22. It therefore arises that when a Member State reserves to take measures towards protecting its official national language (including rules which govern the spelling of that language). The CJEU treats such rules as pursuing a legitimate objective capable of justifying restrictions on the rights of freedom of movement and residence as provided in Article 21 TFEU.

Both Sayn-Wittgenstein and Malgožata Runevič-Vardyn demonstrate that Article 4 (2) TEU can be invoked effectively by Member States against Article 21 TFEU in respect of matters of civil status (determination of surnames) which fall within their exclusive competence. Whether Member States will have the same luck in cases regarding Treaty provisions on the free movement of establishment or services where the applicant's economic activity is at peril (as a result of his/her alteration of surname for example) is another question. It also seems that the CJEU distinguishes between national identity stricto sensu, and its individual declination. While it is stricter with the former, especially in allowing the intricacies of national identity to prevail over fundamental freedoms under the Treaty, it appears more generous with the latter, specifically in order to remove any inconvenience with reference to one's exercise of a profession.

\footnotetext{
${ }^{20}$ Case C-113/89 Rush Portuguesa [1990] ECR I-1417

${ }^{21}$ Case C-213/07 Michaniki [2008] ECR I-9999, para 32.

${ }^{22}$ Case C-208/09 Sayn-Wittgenstein [2010] ECR I-13693.

${ }^{23}$ Case C-391/09 Malgožata Runevič-Vardyn [2011] ECR I-03787.

${ }^{24}$ ibid, para 84,86
} 
We shall draw relevant examples from CJEU case law. On the one hand, in the case of Anton Las ${ }^{25}$, the CJEU decided in April 2013 that a Belgian decree adopted pursuant to the Constitution which specified which language (Dutch) shall be used in the workplace in a particular municipality did not survive the challenge against the freedom of movement of workers provision of Article 45 TFEU. Likewise, the CJEU established that Member States cannot reserve access to the profession of civil-law notary to their nationals because the derogation provided for in Article 45 TFEU must be interpreted strictly and must be restricted to activities which in themselves are linked with the exercise of official authority. ${ }^{26}$

It follows that although the national identity clause offers governments a way to escape some of the obligations that arise under EU law, they enjoy little latitude using Article 4 (2) TEU as a de facto derogation from these obligations. As already explained, in all cases taking place within the scope of EU law, the CJEU will use its established case law on express Treaty derogations and legitimate interests (or objective justifications in indirect discrimination cases) to restrict the impact of the identity clause through the application of the principles of loyalty and proportionality. It is argued that this is in order to 'bind' Member States and exert influence over their behaviour with regard to their loyalty to European integration.

The above trend is manifest with respect to the duties of Member States under secondary legislation on equal treatment of workers. In $\mathrm{O}^{\prime} \mathrm{Brien}^{27}$, for instance, the CJEU precluded Member States from extending the national identity clause to exempt certain public posts (judges) from the application of Directive 97/81 on part-time workers. It held that the UK could not maintain a distinction between full-time judges and part-time judges remunerated on a daily fee-paid basis, unless such a difference in treatment is justified by objective reasons brought in by the national court. The Ministry of Justice's reliance on the independence of the judiciary was not considered to be an appropriate criterion to justify the exclusion of fee-paid Recorders from the scope of the Framework Agreement on part time work.

The CJEU's reluctance to align judicial independence to Article 4 (2) TEU was also manifest in the recent judgment of Commission $v$ Hungary concerning the radical lowering of the retirement age for Hungarian judges. ${ }^{28}$ The CJEU held that although social policy objectives, related to employment policy, the labour market or vocational training, may justify a derogation from the principle prohibiting

\footnotetext{
${ }^{25}$ Case C-202/11 Anton Las [2013] ECR I-0000.

${ }^{26}$ See to that extent Case C-51/08 Commission v Luxembourg [2011] ECR I-4231.

${ }^{27}$ Case C-393/10 O'Brien v Ministry of Justice [2012] ECR I-0000.

${ }^{28}$ Case C-286/12 Commission v Hungary [2013] 1 CMLR 44. No express reference was made to the identity clause of Article 4 (2) TEU.
} 
discrimination on grounds of age, in this case, Hungary failed (on proportionality grounds) to fulfil its obligations under Council Directive 2000/78/EC.

The CJEU took a similar stance in Torresi, a preliminary reference from Italy on the validity of Article 3 of Directive 98/5, which facilitates the practice of lawyers, in light of Article 4 (2) TEU. Inter alia, Italy argued that Directive 98/5 permits the circumvention of national rules regarding the legal profession which form part of the Italian national identity. The question in this case was whether Member States are allowed to make access to the legal profession (a service under EU law) conditional on passing a State examination. ${ }^{29}$ The aspect of national identity or objective reason in this case - i.e. the safeguarding of consumers of legal services and the proper administration of justice failed to pass the CJEU's proportionality test.

The CJEU adopted a freedom of establishment interpretation predicated on the removal of national obstacles. Having said that, the outcome of this case was mainly based on the argument that a lawyer who would be practising under the professional title obtained in another Member State (in this case Spain) would not affect the Italian political or constitutional structures and thus Italy's national identity. Perhaps the outcome would have been different had the Directive in question required Italy to recognise that a lawyer from another Member State can automatically practice under the Italian professional title.

Member States need to be cautious that all future cases employing Article 4 (2) TEU as an EU law qualified derogation will still have to operate within the boundaries established by the CJEU in its case law over the years. Given how prescriptive the CJEU has been about the EU constraints that national legitimate interests have to operate within, there is no much cause for celebration vis-à-vis how much constitutional autonomy can Member States afford by invoking Article 4 (2) TEU as a legitimate derogation.

The CJEU has expressly recognised the aptitude of Member States to safeguard the protection of fundamental rights as enshrined in their constitutions (such as human dignity and equality) and it has entertained the idea of subordinating national legitimate interests to judicial review in all matters related to the internal market. Yet, at the same time, it has stressed that public policy derogations from the Treaty's fundamental freedoms have to be interpreted strictly so as to be applicable only when

\footnotetext{
${ }^{29}$ Case C-58/13 Torresi [2014] ECR-0000. Italy argued unsuccessfully that Art 3 of Directive 98/5 permits the circumvention of national rules regarding the legal profession which form part of the Italian national identity. As such, Italy argued, it is contrary to Article 4 (2) TEU and should therefore be held to be invalid. The CJEU disagreed and adopted a freedom of establishment interpretation predicated on removal of national obstacles.
} 
the case at hand entails a 'genuine and sufficiently serious threat to a fundamental interest of society' ${ }^{30}$ The CJEU also added that the scope of public policy shall not be determined unilaterally by the Member States but shall rather be subject to scrutiny by the EU Institutions.

The above sentiment aside, the CJEU is not prepared to approach all features of Article 4 (2) TEU with a heavy hand and therefore limit their scope of application. In $Z Z$, for instance, the CJEU held in favour of the UK stressing that 'it is clear from Article 4 (2) TEU and Article 346 (1) (a) TFEU that State security remains the responsibility of solely the Member States. The question referred thus relates to an area governed by national law [which is nonetheless separate to identity] and, for that reason, does not fall within European Union competence. ${ }^{31}$ Hence, it can be argued that at least in this case, which concerned an essential state function and not a case of identity, Article 4 (2) TEU served as a means to demarcate national from EU competence. Does this realisation alter what would have happened anyway if, for instance, the UK had brought the public security argument as an objective justification to justify its position? One struggles to see the added value of Article 4 (2) TEU in setting new limits to the CJEU's old jurisprudence on how Member States invoke the Treaty's public policy derogations and judge-made legitimate interest exceptions from free movement law.

\section{B. The importance of the principle of proportionality in the CJEU's 'identity' discourse}

What we can establish from the above analysis of CJEU case law is that the CJEU has managed to provide a very specific explanation vis-à-vis the place of national identity in EU law. It has somewhat shaped the amorphous identity clause of Article 4 (2) TEU. The parallels made in the previous section between the CJEU's past case law on derogations to free movement and its current case law on national identity are supported not only by the similar nature of the rights invoked by Member States but also by the way in which the CJEU balances conflicting interests. In all cases, the CJEU uses the proportionality principle as a means of weighing EU fundamental freedoms against national legislation that protects domestic interests (whether intimate to national identity or not).

The full content of proportionality has derived from the CJEU's jurisprudence as it has been applied over time. With reference to EU action the CJEU has established that the lawfulness of the prohibition of an economic activity is subject to the

\footnotetext{
${ }^{30}$ Case C-208/09 Sayn-Wittgenstein, para 86.

${ }^{31}$ Case C-300/11 ZZ v Secretary of State for the Home Department [2013] ECR I-0000, para 35
} 
condition that the prohibitory measures are appropriate and necessary in order to achieve the objectives legitimately pursued by the legislation in question.' ${ }^{32}$ Conversely, when it comes to assessing Member States' acts, they must not be applied in a discriminatory manner; they must be justified by imperative requirements in the general interest; and they must be suitable for securing the attainment of the objective which it pursues as well as necessary in order to attain it. ${ }^{33}$

The CJEU has decided that Member States enjoy certain discretion to decide on the degree of protection to be achieved with reference to legitimate interests underpinning national regulatory structures such as the protection of public health. This is because, like with ad hoc legitimate interests developed by Member States as a means of preserving their national identity, the level of public health protection may vary from one state to the next. While, however, Member States are afforded a certain margin of discretion to achieve different legitimate objectives, the law which pursues them shall be singular and coherent according to the Treaty. The reference to consistency in Article 7 TFEU qua sincere cooperation under Article 4 (3) TEU (which applies as much to Member States as to the EU itself) is reminiscent of the EU's obligation to set up common principles and unified objectives in EU policies whose aim is to eliminate contradiction. ${ }^{34}$

A similar logic seems to be applying in the way the CJEU is assessing objective justification defences. It follows that national provisions restricting fundamental freedoms under the Treaty to pursue legitimate objectives will only be appropriate if the competent domestic authorities use their discretionary powers according to transparent and objective criteria attaining, in a coherent and systematic manner, the objective pursued. ${ }^{35}$ By contrast, Member States will not be afforded a margin of appreciation where the above basic requirements are not fulfilled, especially when other less restrictive means are available to protect their legitimate interests. ${ }^{36}$

There is a question that emerges with regard to the above proportionality test: Is the test suitable for Article 4 (2) TEU claims given that often national identity rules do not consist of free movement barriers? Indeed, rules on packaging and selling of goods or geographical and demographic restrictions related to the performance of a particular service in the internal market can hardly be invoked as aspects of national

\footnotetext{
${ }^{32}$ See Case C-331/88 Fedesa [1990] ECR-I4023, para 13.

${ }^{33}$ Case C-55/94 Gebhard [1995] ECR I-4165.

${ }^{34}$ See on consistency E. Herlin-Karnell E. and T. Konstadinides, 'The Rise and Expressions of Consistency in EU Law: Legal and Strategic Implications for European Integration' (2013) 15 Cambridge Yearbook of European Legal Studies 139.

${ }^{35}$ See Case C-539/11 Ottica [2013] ECR I-0000, para 44-45.

${ }^{36}$ Case C-265/06 Commission v Portugal [2008] ECR I-2245.
} 
identity in the same way as, for instance, respect for a Member State's high regard for autonomous collective bargaining. ${ }^{37}$ With regard to the latter cases, the CJEU may follow its jurisprudence on fundamental rights. In the past it has established that apart from diminishing Member States' actions under an EU law derogation, fundamental rights may be solely relied upon as an EU law derogation themselves. The CJEU has, likewise, adapted the principle of proportionality to a new approach on the relationship between market freedoms and fundamental rights. ${ }^{38}$

We may recall here that the CJEU has managed pragmatically the conflict between fundamental rights and fundamental market freedoms. ${ }^{39}$ The CJEU has long established that since both the EU and the Member States are required to respect fundamental rights, their protection is a legitimate interest which justifies restrictions upon EU law obligations. Equally, the protection of fundamental rights as an attribute of constitutional identity runs like a leitmotif in the majority of post-Lisbon case law on Article 4 (2) TEU. National identity has been interpreted as synonymous with constitutional autonomy and national self-determination, including concerns over the protection of fundamental constitutional rights or, in pre-Lisbon terms, legitimate interests. Like in Schmidberger, such interests are weighed by the CJEU taking into account all circumstances of the case at hand in order to strike the right balance between them.

The purpose of proportionality in such cases is not only to make sure that the restriction in question shall be suitable for ensuring the attainment of the legitimate objective pursued and shall not go beyond what is necessary to achieve it. Next to suitability and necessity the CJEU has added another limb to its proportionality test, namely proportionality stricto sensu. ${ }^{40}$ This development implies that proportionality may also be employed as an explicit balance of interests.

Yet, the proportionality stricto sensu model is not always functional for the assessment of national identity claims based on Article 4 (2) TEU. There are situations where the CJEU's proportionality test based on suitability and necessity seems somewhat outdated in the post-Lisbon setting. This is because EU law derogations on legitimate interests no longer concern solely the resolution of conflicts

\footnotetext{
${ }^{37}$ Having said that, one may still argue that Member States could resort to national identity to defend internal market restrictions.

${ }^{38}$ Case C-438/05 Viking [2007] ECR I-10779; Case C-341/05 Laval [2007] ECR I-11767.

${ }^{39}$ Case C-112/00 Schmidberger [2003] ECR I-5659; Case C-36/02 Omega Spielhallen [2004] ECR I9609.

${ }^{40}$ The proportionality stricto sensu approach has been supported by CJEU's case law. See, for instance, Case C-283/11 Sky Österreich [2013] ECR I-0000. See also de S.A. Vries, Balancing Fundamental Rights with Economic Freedoms According to the European Court of Justice (2013) 9 (1) Utrecht Law Review 169-192.
} 
arising between the economic and non-economic values and objectives. Instead, two crucial developments have taken place. First, as discussed, most Article 4 (2) TEU cases involve Member States invoking fundamental rights as a means of derogating from EU law. Second, the introduction of Article 4 (2) TEU coincided with the reshuffling of Article 6 TEU which currently boosts the EU's commitment to fundamental rights protection by, inter alia, making the Charter binding and applicable in all cases where Member States are acting within the scope of EU law. ${ }^{41}$

The above developments reveal that the habitual conflict between national law and EU law has transformed and now includes two possible scenarios of discord between the EU and the Member States. The first scenario involves the classic national fundamental rights against EU fundamental freedoms clash examined above. The second scenario is about a more intricate national fundamental rights against EU fundamental rights confrontation. With reference to the second scenario, not only has the Charter's increased relevance as a benchmark for the validity of EU acts helped the CJEU erode the boundary between fundamental freedoms and fundamental rights. It has also given the CJEU a platform to balance constitutional provisions, which may be related to fundamental rights protection in a Member State, with fundamental rights as protected in the EU legal order. This is, however, easier said than done. Since fundamental rights protection at both EU and national level also involve adherence to the European Convention of Fundamental Rights (ECHR) - even more so for the EU after it will have acceded to the ECHR - both CJEU and national judges are confronted with a barrage of hierarchy issues. These issues emanate from the overlapping application of national constitutions, the Charter and the European Convention of Human Rights. ${ }^{42}$

Given that the above balancing exercise is influenced by the principles of sincere cooperation and primacy, it will in most cases conclude in favour of the EU. This is the case even when EU law applies remotely to a domestic situation and even where the threshold of fundamental rights protection is higher in the constitution of a Member State as opposed to the Charter itself. ${ }^{43}$ Thus, it has accurately been pointed out that 'state-specific constitutional guarantees [even dressed-up as aspects of national identity] stand no chance of survival when they collide with the standards set by the Charter'. ${ }^{44}$ What really matters for the CJEU is whether the national provision in question would lead to a result which is contrary to the application of EU law.

\footnotetext{
${ }^{41}$ See Case C-617/10 Åkerberg Fransson [2013] ECR I-0000.

${ }^{42}$ Having said that, see the CJEU's recent Opinion 2/13 on the compatibility with EU law of the draft agreement for EU accession to the ECHR, 18 December 2014, nyr. This Opinion makes it difficult for the EU to proceed with ECHR accession.

${ }^{43}$ See Case C-399/11 Melloni [2013] ECR I-0000.

${ }^{44}$ See F. Fontanelli, 'National Measures and the Application of the EU Charter of Fundamental Rights

- Does curia.eu Know iura.eu?' (2014) 14 (2) Human Rights Law Review 231, 263.
} 
Conversely, the CJEU has made it explicit that national peculiarities endowed with constitutional status will not qualify as exceptions from the application of EU law if they fall below the fundamental rights threshold set by EU law. This is all the more important in light of the Roma repatriation crisis in France in $2010^{45}$, the constitutional crisis in Hungary in $2011^{46}$ and the political crisis in Romania in $2012^{47}$. Although national identity was not expressly mentioned in any of these cases, future reliance on the identity clause could allegedly assist certain Member States to unilaterally escape the all-inclusive character of European integration with all the consequences that such conduct may generate. ${ }^{48}$

Despite the fact that none of the abovementioned crises generated litigation, it is likely that in future the Commission may take action under Article 7 TEU to restore the rule of law. ${ }^{49}$ For instance, it is expected that where the invoked aspect of national identity falls below the EU's standard of fundamental right protection, the CJEU would stress that national identity shall be broadly defined in conformity with the traditional democratic values underpinned in Article 2 TEU such as respect for democracy, fundamental rights and the rule of law. It is likely that the CJEU would be explicit that anything falling below such a minimum level of protection would jeopardise the EU's constitutional integrity or, dare we say again, EU identity.

\section{CONSTITUTIONAL IDENTITY IN DOMESTIC JUDICIAL PRACTICE}

\section{A. Towards a typology of Identity Retention cases}

So far we may agree that constitutionalising national identity in the Treaty adds little value to resolving (at least in favour of the Member States) the question about whether EU legislative acts should claim primacy upon fundamental constitutional provisions. This is the case because of the generic language used by the drafter in Article 4 (2) TEU and the CJEU's restrictive interpretation of it. Put simply, as far as

\footnotetext{
${ }^{45}$ D. Castle and K. Bennhold 'Dispute Grows Over France's Removal of Roma Camps' (The New York Times, 16 September 2010) Available at: <http://www.nytimes.com/2010/09/17/world/europe/17union.html?_r=0>; 'EU may take legal action against France over Roma' (BBC, 14 September 2010) Available at: $<$ http://www.bbc.co.uk/news/world-europe-11301307> ;

46 'Hungary's new constitution 'puts democracy at risk' (BBC, 20 June 2011) Available at: http://www.bbc.co.uk/news/world-europe-13843400

47 'EU warns Romania PM Victor Ponta over political crisis' (BBC, 12 July 2012) Available at: $<$ http://www.bbc.co.uk/news/world-europe-18822790>

${ }^{48}$ See V. Reding, 'The EU and the Rule of Law - What next?' Speech: The EU and the Rule of Law What next? European Commission - SPEECH/13/677, 04/09/2013.

${ }^{49}$ C. Closa et al, 'Reinforcing Rule of Law Oversight in the European Union' Robert Schuman Centre for Advanced Studies Research Paper No. 2014/25. Available at <http://ssrn.com/abstract=2404260>.
} 
the CJEU is concerned, national identity does not comprise a real limit to the transfer of sovereign powers to the EU. Therefore, the case law emanating from the CJEU has sufficiently marginalised Article 4 (2) TEU. The identity clause constitutes a Treaty derogation which is subject to the same limitations as all other express derogations found in the Treaty regarding the scope of EU fundamental freedoms. This outcome prompts us to consider whether the CJEU's interpretation of Article 4 (2) TEU is amenable to Member States and their constitutions as a complex set of precommitment strategies (through which the citizenry establishes arrangements to safeguard the integrity of the constitution from EU self-interest and other problems in EU democratic governance), and whether national judges have found other avenues outside Luxembourg to protect constitutional identity.

Despite the CJEU's somewhat restrictive interpretation of Article 4 (2) TEU, Lisbon's renewed commitment to the protection of identity has presented national courts with an opportunity. Indeed, outside the CJEU's premises, Lisbon's Article 4 (2) TEU has provided national judges with a tool to theorise about the likelihood of placing EU identity-encroaching acts under close judicial scrutiny at home. ${ }^{50}$ In this respect, the CJEU's interpretation of Art 4 (2) TEU is not as much as an obstacle and the review by national courts is based on constitutional identity as seen separately from national identity under Art 4 (2) TEU. Moreover, national courts would likely not even consult the CJEU on the interpretation of the concept of constitutional identity. We should, therefore, take a step back from Article 4 (2) TEU and emphasise the vital role of national constitutional provisions already in place prior to the coming into force of the Lisbon Treaty which are intended to police identity-encroaching acts. It is important to juxtapose national identity as it features in constitutional law (or simply, constitutional identity) against Article 4 (2) TEU in order to avoid confusion. The former is interpreted by national judges whilst the latter by their European counterparts.

Thus, when it comes to Member States defending their constitutional identity, two streams of cases broadly stand out. First, we come across cases where constitutional courts act as the final constitutional arbiters of competence transfer regarding the signing and ratification of a new EU Treaty or Act of Accession (e.g. new Member States). This is a review in which the majority of national constitutional and highest courts engage in, especially when a substantial change takes place in the final agreement that their governments are called to sign. Second, national courts use national identity to habitually review the compatibility of EU law with the

\footnotetext{
${ }^{50}$ This happened five years prior to the Lisbon Treaty coming into force when certain national courts scrutinised Article I-5 (the predecessor of Article 4 (2) TEU) in light of Article I-6 (clause on primacy) of the ill-fated EU Constitutional Treaty. See for instance, Spanish Constitutional Tribunal, Declaration on Establishing a Constitution for Europe, DTC 001/2004, para 4.
} 
Constitution in the context of transposition of pervasive EU secondary legislation. In both cases, the Member States' models of identity review remain, up to the present day, a theoretical possibility and, therefore, idle. Nonetheless judicial review is intended to create a further constitutional check on EU integration by protecting rights and promoting deliberative democracy at home. We will therefore, look at the above categories and examine the theoretical benefits and constraints of identity review in the Member States with regard to posing legal limits that be delimited and discerned with some clarity. We will also enquire whether there are new types of cases where national courts have resorted to their identity review.

\section{i) National Identity in the context of Treaty Ratification / Accession Treaties}

In the first category of cases (constitutionality of Treaties), national courts generally stress that the principle of a state ruled by law and the doctrine of popular sovereignty (democracy) are unamenable to change. In other words, the transfer of competence to the EU has to respect certain limits. National judges seem reticent to engage in a pluralist interpretation when it comes to higher constitutional principles and, therefore, establish any dialogue with their European counterparts. The idea is that if Treaty amendment gives rise to a more extensive delegation of the competence to the EU and a more extensive interference with the national constitution, it is necessary to seek the approval of the people as the holder of supreme power and presumably amend the Constitution to that effect.

The above take on identity is hardly new. It is implicit in judicial reasoning across most Member States. It has been particularly prominent in Denmark, Germany, Italy and a number of new Member States which have ruled on the compatibility of a Treaty amendment or an Accession Treaty with their constitutions. In this context, it is unlikely that national courts will refer to the CJEU something that the latter Court has no competence to adjudicate on - i.e. the compatibility of what in effect is a new Treaty with their national constitutions. In this regard, it is for the courts of Member States to ascertain the compatibility of EU law with national law by looking inwards and explaining the position on ratification by reference to the constitutional document as the highest law.

In Denmark, for instance, according to para 20 of the Constitution any delegation of powers can take place only to 'international authorities' established by 'mutual agreement' with 'other states' for the promotion of 'international rules of law and cooperation'. ${ }^{51}$ It is assumed that according to the Constitution no transfer of powers

\footnotetext{
${ }^{51}$ Denmark: Hojesteret, Judgment of 6 April 1998. The issue was whether the Maastricht Treaty was rightly implemented in conformity with s. 20 of the Constitution or whether such implementation required an amendment of the Constitution.
} 
can take place to such an extent that Denmark can no longer be considered an independent state. The determination of the limits of power transfer must rely almost exclusively on considerations of a political nature. Likewise, in Italy the Constitutional Court (Corte Costituzionale) has principally recognised the primacy of EU law as well as the monopoly of the CJEU over its interpretation but has reserved the right to 'review the act implementing the Treaty as regards compliance with basic [...] principles of the Italian Constitution and the inalienable rights of the person.'52 Hence the Corte Costituzionale has reserved the right to examine the constitutionality 'of the continuing compatibility of the Treaty with the said principles' even at risk that such an approach could call into question Italy's remaining in the EU.

We can deduct that constitutional identity as understood by the majority of Member States has historically, but rather implicitly, provided protection in the process of assessing the compatibility of Treaty revision with a Member State's democratic mandate. The important role of direct democracy, as a prime expression of constitutional identity, has been expressed in some Member States through the occasional use of referendums. Such has been the case in Ireland where in Crotty $v$. An Taoiseach the Irish Supreme Court stressed that that Ireland could not ratify the Single European Act unless the Constitution was changed - by means of referendum to allow the ratification. More recently, the Spanish Constitutional Tribunal expressed similar reservations with reference to the existence or absence of contradiction between the Constitution and the EU Constitutional Treaty. Following a confirmation of its compatibility with the Spanish Constitution a successful referendum was held in Spain. $^{53}$

Younger Member States have also expressed similar concerns to their counterparts with reference to the role of democracy and sovereignty in the process of EU Accession or Treaty revision. In Poland, in a case concerning Poland's accession to the EU, the Constitutional Tribunal stressed that the Constitution prevents the transfer of competences insofar as it would lead to the Republic's loss of a status as a sovereign State. ${ }^{54}$ In Latvia, on the other hand, in a case concerning the constitutionality of the Lisbon Treaty, the Constitutional Court found that the Treaty did not have an influence on state sovereignty and democracy as enshrined in Article 2 of the Constitution. ${ }^{55}$ A Similar stance was adopted by the Czech Constitutional

\footnotetext{
${ }^{52}$ Corte Costituzionale, Decision no. 183/1973

${ }^{53}$ Tribunal Constitucional, Judgment of 13 December 2004, DTC 001/2004.

${ }^{54}$ Trybunal Konstytucyjny, Judgments of 11 May 2005, K 18/04.

${ }^{55}$ Satversmes Tiesa, Judgment of 7 April 2009.
} 
Court in which, in its judgment concerning the ratification of the Lisbon Treaty, held that the ratification of the Lisbon Treary carried with it no loss of sovereignty. Having said that, the Czech Constitutional Court was explicit about the fact that a change in the essential requirements for a democratic state governed by the rule of law is impermissible by explicit wording of the constitution, and that legal norms may not be interpreted in such a way as to threaten the democratic foundations of the state. ${ }^{56}$

The above constitutional barriers for further integration are also inherent in the German tradition and were exemplified by the BVerfG in its seminal Lisbon Urteil. The difference with the approaches examined above lies in that the BVerfG made explicit reference to constitutional identity in the context of Treaty amendment as an instrument of internal judicial review. The BVerfG agreed that constitutional identity is encapsulated in a number of unalterable principles (such as human dignity, freedom, equality, justice and other essential democratic principles) under the eternity clause of Article 79 (3) GG which in some ways are reminiscent of the EU objectives listed in Article 3 TEU ${ }^{57}$ It was emphasised that these principles are not susceptible to amendment without express conferral by the German citizenry. The BVerfG, therefore, linked the constituent power of popular sovereignty with democratic selfdetermination (i.e. the right to vote) of the peoples of the Member States. The Lisbon Urteil is an enormously symbolic decision because it made it explicit that constitutional claims in Germany would not only take place when EU Institutions act beyond their attributed powers but also when the constitutional identity of the Grundgesetz is going to be distorted as a result of a serious shift in competence delimitation.

The German concept of identity has received a lot of attention because it is the most indicative example of the constitutional identity trend as it relates to areas which cannot be subject to revision within the normative framework of the Constitution. In its extreme form, however, an insular expression of constitutional identity may trigger constitutional patriotism (Verfassungspatriotismus), a concept revived in the Lisbon Urteil. ${ }^{58}$ It is worth mentioning that in crafting its identity review, the BVerfG made reference to the majority of national courts mentioned above. This was perhaps a symbolic gesture aimed at demonstrating that first, constitutional reservations are not the BVerfG's absolute privilege and second, that they have not been shared by all

\footnotetext{
${ }^{56}$ See for instance the Czech Constitutional Court's (CC) Second Lisbon Judgment (Treaty of Lisbon II), 3 November 2009, PI ÚS 29/09. The CC ruled that the Lisbon Treaty was not in breach of the Czech Constitution and distanced itself from the BVerfG's Lisbon Urteil.

${ }^{57}$ Lisbon Urteil, Judgment of 30 June 2009, BVerfG 2BvE 2/08, paras 211, 217.

${ }^{58}$ See J.E. Khushal Murkens, 'Identity trumps Integration. The Lisbon Treaty in the German Federal Constitutional Court' (2009) 48 (4) Der Staat 517.
} 
national courts with the same intensity. It also demonstrates a certain degree of mutual influence of national courts at the horizontal level.

The above cross-reference was repeated by the Polish Constitutional Tribunal which in a case regarding the constitutionality of the Lisbon Treaty, it decided to look into national identity cases from other Member States' constitutional courts. ${ }^{59}$ Indeed, German judicial practice on constitutional identity review has been influential for constitutional and high courts of other Member States. ${ }^{60}$ For instance, in an internal case regarding the possibility for judicial review of the Croatian Special Tax Act, the Croatian Constitutional Court quoted the BVerfG as an authority in determining the borderline on which constitutionalism of social rights clashes with democracy. The Constitutional Court referred to the problem created by the expression of social state and social justice as principles of constitutional identity. It noted that the standards for determining the borderline in case law were formulated by the BVerfG and they are today considered to be the 'ruling guidelines for the work of the European courts. ${ }^{61}$ At the same time, however, some national constitutional courts have expressly rejected several key arguments raised by the BVerfG - one of them relating to the judicial application of eternity clauses and the concept of identity. ${ }^{62}$

So far we may argue that the contribution of national courts in the context of Treaty amendment or accession is essential in enhancing our understanding about setting limits to EU law's uniform application qua the fundamental values inherent in domestic legal systems including those akin to constitutional identity which may hinder the force of EU Treaties. What follows is a discussion on the increasing judicial emphasis on constitutional identity retention in other Member States outside the context of Treaty amendment or accession to the EU. We will look into identity as a potential means of reviewing EU secondary legislation. There, identity retention is not presented as an absolute constitutional checkpoint.

\section{ii. National Identity in the context of Secondary Law Implementation}

In the second category of cases (implementation of EU secondary legislation), identity constitutes a standard invoked where the constitutionality of statutes

\footnotetext{
${ }^{59}$ Trybunał Konstytucyjny, Judgment of 24 Novemner 2010, K 32/09.

${ }^{60}$ See for an indicative list: Gauweiler (or OMT decision), Judgment of 14 Jan 2014, BVerfG, 2 BvR 2728/13, para 30 (cc). The BVerfG mentioned a number of cases decided by the Supreme Courts of Denmark, Estonia, Ireland; the Italian and Czech Constitutional Courts and the Polish and Spanish Constitutional Tribunals as well as the French Constitutional Council (considered in more detail below). According to the BVerfG these cases serve as examples of the protection of constitutional identity in other Member States and of the limits of transfer of sovereign powers to the EU.

${ }^{61}$ U-IP 3820/2009 and Others, Judgment of 17 November 2009.

${ }^{62}$ See case comment by J. Komarek in (2009) 5 (3) European Constitutional Law Review 345.
} 
transposing EU secondary legislation is being challenged vis-à-vis the rules and principles inherent to constitutional identity. This take on identity is less frequent and it lacks a common denominator in all Member States (e.g. popular sovereignty). Each national court places different emphasis on constitutional premises that it regards as essential and, therefore, immune from the tidal effect of EU law. Furthermore, while in the previous category Member States could legitimately subject the signing of a new Treaty to an internal identity review, they do not seem to be able to do the same with regard to the transposition of secondary legislation. This is because the latter goes hand in hand with the principle of sincere cooperation under Article 4 (3) TEU. Hence, with the exception of cases of manifest breaches of EU constitutional values by EU secondary legislation, a unilateral identity review as a countermeasure does not appear to be practical or feasible. Even in such cases, national judges are subject to the norms of the Constitution which in most cases also encompasses the duty to apply EU law binding upon the Member States.

The above realisation is important in the context of the theoretical scenario where a national court finds a piece of EU secondary legislation to be strikingly contrary to the State's constitutional identity. For example, in a case concerning the problem of compatibility of an EU Regulation with the Polish Constitution, the Polish Constitutional Tribunal stressed that although the Constitution takes supreme position over all sources of law (including EU law) it is difficult to reconcile constitutional identity with the principle of sincere cooperation which poses a duty for the Member States to show the highest standard of respect for EU norms. The Polish Constitutional Tribunal stressed that this is an important consideration to have in mind when examining the possibility of adopting an insular approach to identity retention against one based on dialogue between the national and European judges. ${ }^{63}$ In this context, it is understandable why only under exceptional circumstances would national courts be prepared to act ultima ratio and, thus, review whether an act of the EU institutions exceeds the transferred powers.

Not all states have placed the same emphasis on the principle of sincere cooperation. This is especially when the competences that have been transferred to the EU and its integration programme prove to be unpredictable. As regards national transposition of EU secondary law in Germany, the BVerfG has adopted an approach which transgresses the State's loyalty obligation where legal protection of the core content of the constitutional identity cannot be obtained at EU level. It stressed in its Data Retention Directive implementation judgment, that Germany's constitutional identity charges the State with the task of preserving the citizens' enjoyment of fundamental

\footnotetext{
${ }^{63}$ Re: Constitutionality of EU Secondary Legislation (Regulation (EC) No 44/200) Judgment of 16 November 2011 - Ref. No. SK 45/09.
} 
rights (e.g. the right to privacy) in both regional and international connections. ${ }^{64}$ Although this review produces an outcome that can hardly be described as cooperative, the EU Institutions can, at least in theory, hardly oppose it in cases of obvious transgressions. ${ }^{65}$ And there are such cases. In the Data Retention Directive dispute, the right to privacy was profoundly breached. In the end, however, Germany did not use its identity review but rather fulfilled its obligations under the Treaty and implemented the Directive (2006/24/EC) which was subsequently annulled by the CJEU in a private action against its implementation for its incompatibility with the right to privacy. ${ }^{66}$ Conversely, the Romanian Constitutional Court declared unconstitutional the domestic provision that transposed the Data Retention Directive. ${ }^{67}$ The CJEU decided the case without making reference to EU law. It emphasised that state intervention must comply with strict rules, expressly mentioned in Article 8 ECHR, Article 53 of the Constitution and the principle of proportionality vis-à-vis the continuous retention of data, respectively. ${ }^{68}$

The fact that so much emphasis has historically been placed on the German experience is merely because the BVerfG regards itself to be competent for deciding whether an act of secondary law is ultra vires. As also discussed earlier, according to its Lisbon Urteil, the BVerfG will also scrutinise the exercise of EU competences through an identity review in order to preserve the inviolable core content of Germany's constitutional identity. This does not suggest, however, that the German jurisprudence on constitutional identity is pioneering. The truth is that it came rather late to become a focal point for other national courts - at least in the context of implementation of secondary legislation. For instance, the French identity jurisprudence on the constitutionality of EU secondary legislation started in 2006 (if not before ${ }^{69}$ ), three years before the German Lisbon Urteil.

The French Constitutional Council (Conseil Constitutionel - CC), which is the highest constitutional authority in France, has asserted its jurisdiction to review the conformity with constitutionally guaranteed rights and freedoms of provisions which draw from EU secondary law solely when a rule or principle inherent in France's

\footnotetext{
${ }^{64}$ Data Retention Directive National Implementation, Judgment of 2 March 2009, 1 BvR 256/08. See for detail on the constitutionality of EU data retention legislation. T. Konstadinides, 'Mass Surveillance and Data Protection in EU Law: The Data Retention Directive Saga' in M. Bergström and A.J. Jonsson Cornell (eds.) European Police and Criminal Law Cooperation (Oxford, Hart Publishing, 2014). Chapter 5, 69.

${ }^{65}$ Having said that, the Commission initiated a number of Article 258 TFEU actions against Member States who had not implemented the Data Retention Directive on time. See T. Konstadinides above.

${ }^{66}$ Joined Cases C-293/12 and 594/12 Digital Rights Ireland and Seitlinger and Others (2014) nyr.

${ }^{67}$ ROM-2010-1-001, Available from < http://www.venice.coe.int/files/Bulletin/B2010-1-e.pdf>

${ }^{68}$ Nonetheless, soon afterwards, Romania implemented the Directive due to action taken by the Commission against it under Article 258 TFEU. 
constitutional identity (identité constitutionnelle) is called into question. ${ }^{70}$ The current stance of the CC with reference to the duty to implement EU legislation marks a shift from the position which was valid up until recently and which placed the emphasis solely upon the express and specific provisions of the French Constitution to an identity-centric one. Yet, contrary to Germany, constitutional identity in France is only a means of avoiding the constitutional obligation to transpose EU Directives into national law. This obligation is by virtue of the amended French Constitution which provides under Article 88-1 that the Republic shall participate in the EU.

The Republic shall participate in the European Union constituted by States which have freely chosen to exercise some of their powers in common by virtue of the Treaty on European Union and of the Treaty on the Functioning of the European Union, as they result from the treaty signed in Lisbon on 13 December, 2007.

Hence, it appears that the $\mathrm{CC}$ brought forward the notion of constitutional identity as a trap-door or exception from the general constitutional obligation to transpose EU Directives if they conflicted with an explicit provision of the Constitution. It is worth mentioning that although the notion of constitutional identity did not appear in the early decisions of the CC interpreting Article 88-1 one could see why a new limit was set by the CC. The dilemma faced by France to comply with its EU law obligations (transposition of secondary legislation) while showing respect for the hierarchy of norms (recognition of the supremacy of the constitution) is manifest in its early case law concerning copyright. ${ }^{71}$ The CC provided that:

[...] the transposition of a Directive cannot run counter to a rule or principle inherent to the constitutional identity of France, except when the constituting power consents thereto[.]

The foregoing provisions thus show, firstly, that the abovementioned Directive...does not run counter to any rule or principle inherent to the constitutional identity of France, and contains unconditional and precise provisions $[\ldots]$

The 2010 decision on the review of the constitutionality of the Act pertaining to the Opening up to Competition and the Regulation of Online Betting and Gambling marks the most recent formulation of the CC's tribute to national identity. ${ }^{72}$ The CC stressed that the review which it carries out vis-à-vis the transposition into domestic

\footnotetext{
${ }^{70}$ 2010-79 QPC, December 17th 2010, para. 3, p. 406

${ }^{71}$ Decision No 2006-540 DC on Copyright and related rights in the Information Society, para 19, 28.

${ }^{72}$ Decision No 2010-605 DC on the Act pertaining to the opening up to competition and the regulation of online betting and gambling of 12 May 2010, Rec. 78
} 
law of a Directive 'cannot run counter to a rule or principle inherent in the constitutional identity of France unless the Constituent power has agreed to the same.' In all events, the $\mathrm{CC}$ has highlighted the duty of all French courts to review the compatibility of a domestic statute with France's EU commitments and, if necessary, to make use of the preliminary reference procedure. ${ }^{73}$ This approach although characterised by a set of peculiarities, both substantial and procedural, that are different to the BVerfG's approach has continued a growing trend amongst national constitutional courts where they seem to have swallowed their pride and availed of the opportunity to make preliminary references to the CJEU. ${ }^{74}$

To summarise the position in France, constitutional identity has been construed very narrowly compared to the wide German interpretation examined previously. For instance, it will only be invoked in exceptional circumstances - when the EU jeopardises the essential features of the Republic (l'essentiel de la République). The latter encompasses any principle that is inherent in French constitutional identity, in both senses of the word 'inherent' - i.e. crucial and distinctive (crucial et distinctif). ${ }^{75}$ Such would be for instance the principle of laïcité or, in its closest English translation, secularism. ${ }^{76}$ Similarly, the constitutional salience of Catholicism in Ireland and the ban on abortion in its constitution could be perceived as essential to Ireland's constitutional identity.

The UK is also new to the constitutional identity retention trend. Nonetheless, the constitutional ground is fertile for such a development. Despite the absence of a written constitution in the UK, there are a host of constitutional instruments which are almost eight hundred years old and regulate inter alia the relationship between the Crown and Parliament, the administration of justice and the application of the common law. In spite of the availability of the identity clause, UK courts have not yet made use of it. The Supreme Court has, however, almost flirted with the BVerfG's

\footnotetext{
${ }^{73}$ See more recently on the above-mentioned double constitutional restriction: 2011-631 DC June 9th 2011, 252 para.45. While the CC states in this case (as it has done before) that within the framework of an Article 61 procedure it cannot itself refer a preliminary question to the CJEU (it can and it did so within the framework of a question prioritaire de constitutionnalité). See also for more detail on the role of Conseil Constitutionnel: S. Wright, 'The French Conseil Constitutionnel since Mid-2007: Its Role in an Ever-Changing Landscape' (2010) (16) 4 European Public Law 539.

${ }^{74}$ See two recent CJEU's decisions deriving from requests for preliminary rulings under Article 267 TFEU from the Tribunal Constitucional (Spain) and the Council Constitutionnel (France) in Case C399/11 Melloni [2013] ECR-I 0000 and Case C- 168/13 PPU Jeremy F v. Premier Ministre [2013] ECR-I 0000 respectively.

${ }^{75}$ See Echange de voeux à l'Elysée, Voeux du Président du Conseil Constitutionnel, M. Pierre Mazeaud, au Président de la République, 3 janvier 2005. Available at <http://www.conseilconstitutionnel.fr/conseil-constitutionnel/francais/relations-exterieures/agenda/le-conseil-en2004/voeux-a-l-elysee.5147.html>

${ }^{76}$ See Oral Submission by J.H.H. Weiler in the Lautsi Case before the ECHR, 30 June 2010. Available at < http://eclj.org/pdf/weiler_lautsi_third_parties_submission_by_jhh_weiler.pdf>
} 
approach in implicitly qualifying certain national provisions as encapsulating part of the country's constitutional identity. ${ }^{77}$ In doing so, the Supreme Court has resorted to a unilateral assessment of which cases are to be considered internal and, therefore, to be decided at home behind closed doors and which cases are to be up for discussion with the CJEU.

The above logic was recently confirmed in the Supreme Court's (SC) reasoning in the $H S 2$ case concerning an unsuccessful challenge against the high-speed rail link between London and the West Midlands brought by $\mathrm{H} 2$ Action Alliance, nine Local Authorities and Heathrow Hub Ltd. ${ }^{78}$ The claimants argued that both the Government's consultation process (which preceded the Parliamentary hybrid Bill) and the hybrid Bill procedure failed to comply with the relevant EU legislation on environmental impact assessment. The SC unanimously dismissed the appeal from the Court of Appeal based on the claim that the government had failed during its consultation process to make a strategic environmental assessment in compliance with Directive 2001/42/EC.

What is important here is the way in which the SC clarified the scope of EU law visà-vis the judicial supervision of the internal proceedings of national legislatures. It established that the latter is only appropriate in case of breach of a constitutional guarantee. The SC contended that the Directive in question cannot be invoked to review the adequacy of Parliament's consideration of environmental assessment. Likewise, national courts cannot strike down legislation if they conclude that the legislature's consideration of the environmental assessment was inadequate. To cut a long story short, the judiciary, cannot by virtue of EU law, subject to oversight the inner workings of the legislature. It is remarkable that the SC linked the above argument with the separation of powers as being the dominant principle that binds constitutional democracies. It did so in a way which is akin to the use of constitutional identity by other domestic courts examined in this article.

The SC acknowledged, however, that the doctrine of separation of powers has different manifestations in the Member States which give life to diverse readings of judicial discretion to review legislative choices. Furthermore, the SC was explicit that the internal proceedings of Parliament form an aspect of the identity of the British Constitution. As such, they are immune from judicial review or supervision by national courts. Referring to the BVerfG, the SC indicatively stated that:

\footnotetext{
${ }^{77}$ No reference was made to Article 4 (2) TEU.

${ }^{78} R$ (o.t.a HS2AA, Buckingham County Council and others) v. Secretary of State for Transport [2014] UKSC 3
} 
There is [...] much to be said for the view, advanced by the German Federal Constitutional Court in its judgment of 24 April 2013 on the Counter-Terrorism Database Act [...] that as part of a co-operative relationship, a decision of the Court of Justice should not be read by a national court in a way that places in question the identity of the national constitutional order. $^{79}$

Hence, it is not only important that the SC refused to refer the matter to the CJEU because the command paper was merely a proposal and not a framework for decisionmaking as such. The SC mentioned that even in the event it had to refer a question for a preliminary ruling, the nature and status of a command paper of the kind in the case at hand constituted a question of national law and practice. Accordingly, national courts are in a position to verify that the requirements of a Directive have been satisfied, taking account of the entire legislative process, including the preparatory documents and Parliamentary debates.

The SC raised Article 9 of the Bill of Rights 1689 which implies that a primary function of Parliament is to debate and pass resolutions freely on subjects of its own choosing. Courts cannot question the nature of parliamentary proceedings. This is a classic example of another doctrine, that of self-restraint (i.e. courts intervene only in the most extreme circumstances) ${ }^{80}$. The process by which legislation is enacted in Parliament is, therefore, key to the British constitutional identity. In the event the principles regarding the function of Parliament, as enshrined in the Bill of Rights, conflict with a provision of EU law, such conflict would have to be resolved internally before national courts 'as an issue arising under the constitutional law of the UK' and not by reference to the famous Factortame decision.

Let us be reminded that the Factortame concerned an injunction to suspend an Act of Parliament (the Merchant Shipping Act of 1988) - i.e. an ordinary statute - because of its incompatibility with directly effective rights under EU law, in particular the prohibition of discrimination on grounds of nationality and the freedom of establishment. ${ }^{81}$ By contrast, HS2 was essentially a case about Article 9 of the Bill of

\footnotetext{
${ }^{79}$ ibid, para 111

${ }^{80}$ See Associated Provincial Picture Houses v Wednesbury Corporation (1947) 1 KB 223. See also J. Jowell and A. Lester, 'Proportionality and Wednesbury Unreasonableness: The Influence of European Legal Concepts on UK Law in M. Andenas (ed.) English Public Law and the Common Law of Europe (Key Haven Publishing, London 1998). By contrast, as previously discussed, the BVerfG has not demonstrated the same reluctance to scrutinise administrative decisions. On the contrary, the BVerfG's review is rather invasive.

${ }^{81}$ See on Factortame: Jay J. Arangones 'Regina v. Secretary of State for Transport Ex Parte Factortame Ltd:: The Limits of Parliamentary Sovereignty and the Rule of Community Law' (1990) 14 (3) Fordham International Law Journal 778. See on implications to national sovereignty: P. Craig,
} 
Rights 1689 which embodies a constitutional principle related to the status of proceedings in Parliament - i.e. a constitutional statute (a concept developed after Factortame). ${ }^{82}$ As such it was for British courts to answer the question of whether the European Communities Act 1972 implicitly diminished Article 9 of the Bill of Rights which sets express limits to judicial intervention in the legislative process.

Given the above, the main method of identifying constitutional identity is related to national law - i.e. the content of the Constitution and the highest domestic courts' relevant jurisprudence. It reflects selfhood and is characterised by the need to keep the application of EU law in check. It is argued that while the German approach is an isolated position based on Article 79 (3) GG which makes certain amendments to the Grundgesetz inadmissible, the French is more moderate in that both the application of EU law and its limits constitute two sides (or expressions) of the same coin (sovereignty). As such, French judges avoid giving substance to the constitutional identity of France from the outset. They even refrain from creating a positive list of aspects of constitutional identity. They rather prefer not to engage in a process of balancing the exercise of sovereign expressions vis-à-vis the application of EU law and its limits. This approach is frequented by most Member States in their domestic decisions regarding the application of primacy of EU law and it is a workable solution to the tension between the two parallel universes (domestic and European) of identity protection.

The British attitude is somewhat a hybrid between the German and the French approach. While it is established that the effectiveness of EU law within the UK legal system is attributable to the European Communities Act 1972, the Supreme Court avoids referring a matter to the CJEU when certain constitutional statutes conflict with EU law. Nonetheless, the conflict is still hypothetical at this point since HS2 was based on compliance with EU law. In all cases, however, the Supreme Court demonstrates respect for the principle of separation of powers locating constitutional identity in the model of the governance of the state. It follows that no EU legislation can compel domestic courts to set aside such a fundamental principle although this is still to be determined.

The British approach is somewhat different, however, to the BVerfG which generally locates constitutional identity as the individual rights of the voters. In doing so, the BVerfG somewhat endangers the separation of powers in Germany by playing a more active role than the German legislature in securing the effective protection of constitutionally-entrenched rights. But do we now for sure that the UK Supreme

'Sovereignty of the United Kingdom Parliament after Factortame' (1991) 11 Yearbook of European Law 221.

${ }^{82}$ For Factortame, an ordinary statute was supreme. 
Court would not have done exactly the same thing (i.e. legislating policy from the bench) if it ruled against the EU? Is it not right for judges to make law but only apply it? Indeed, the practice of judicial lawmaking in Europe has accelerated in the past five decades. After all, the EU is leading by example. The founding fathers of EU law regarded the CJEU as an important repository for representation and preservation of the EU ideals.

Taking the above debates into perspective, we can make two preliminary conclusions. First, the inter-judicial effects of identity retention with regard to the validity of secondary legislation are not monocausal and second that, with the exception of the brief reference made by the Supreme Court judges in London to their counterparts in Karlsruhe, we are still some way from having a mutual influence and dialogue of national courts at the horizontal level so as to achieve a certain level of uniformity in the protection of constitutional identity in the Member States. Further thought needs to be put into how express comparative reasoning by national courts in this context can help Member States iron out the controversies concerning the use of national identity as a unilateral review formula of EU secondary legislation. Our study suggests that constitutional identity functions as a last resort guardian of systemic values at the heart of the Member States legal systems against the implementation of EU secondary law in cases of manifest breaches of fundamental rights; the separation of powers or any value which is akin to the essentials of the state. In such cases, it appears that national courts provide that the State does not have to be favourably inclined towards the EU.

\section{iii. Identity review outside the context of Treaty revision or secondary law implementation}

As already explained, the theoretical significance of national identity retention lies in that it provides national courts with a means of unilaterally exercising judicial review against EU law. As mentioned, the manner in which constitutional identity is elucidated in Germany is particularly important because German constitutional judges have reserved the right to carry out identity and ultra vires reviews exclusively for themselves and have progressively detached the protection of constitutional identity at both EU and national level. The fact that a national court has taken upon itself to act as a court of final constitutional appeal for the EU is, nonetheless, problematic for the unity of EU law. This is especially because new situations have been identified where the BVerfG has raised the theoretical possibility of constitutional objections to defend its constitutional identity from EU legislation beyond Treaty revision or transposition of secondary legislation.

Following a number of cases on the application of the EU Charter of Fundamental Rights, the BVerfG made it clear that the Charter's provisions do not extend EU 
competences as defined in the EU Treaties. Not only has the BVerfG has charged itself with the task of defending constitutionally-entrenched fundamental rights; it has also attempted to measure the impact of the Charter on the division of competence for the protection of fundamental rights between the CJEU and national constitutional courts. In a 2013 case regarding the constitutionality of a German anti-terrorist database, ${ }^{83}$ the BVerfG sent 'a loud signal to the CJEU' following the latter's controversial judgment in Akerberg Fransson with reference to the principle of ne bis in idem (laid down in Article 50 of the Charter) in taxation cases. ${ }^{84}$ In the Terrorist Database case, the BVerfG warned the EU Institutions that it will react to any future unprecedented expansion of the EU's competence in fundamental rights protection obtained through the application of the Charter to areas whose link with EU law is too tenuous.

Most recently, in ascertaining the BVerfG has challenged the validity of the decisions of sui generis institutions, such as the ECB, operating within the EU institutional system. Identity review may be applied outside the context of Treaty revision or secondary law implementation qua an act of an EU institution such as the ECB that has its own legal personality and decision-making bodies (e.g. Governing Council, Executive Board). ${ }^{85}$ In Gauweiler the dispute concerned the legality of the ECB's government bond buying program which was put together in order to defuse the Eurozone financial crisis. There were two main issues in the case. First, the BVerfG contested the validity of the Decision of the Governing Council of the ECB on Technical Features of Outright Monetary Transactions (OMT) arguing that it violates EU rules on monetary policy as envisaged by Articles 119 and 127 (1) and (2) TFEU and the Protocol on the Statute of the European System of Central Banks and of the ECB (Articles 17-24).

The core of the BVerfG's argument is that the scheme is unlawful because it authorises the ECB to make unlimited purchases of sovereign bonds on the secondary market and, thus, intermingles monetary policy with fiscal policy. ${ }^{86}$ The ECB should

\footnotetext{
${ }^{83}$ Counter-Terrorism Database Act Decision of 24 April 20131 BvR 1215/07,

${ }^{84}$ Case C-617/10 Aklagaren v. Hans Åkerberg Fransson, judgment of 26 February 2013 [2013] ECR-I 0000. See F Fontanelli, 'Anti-terror Database, the German Constitutional Court reaction to Akerberg Fransson - From the spring/summer 2013 Solange collection: reverse consistent interpretation' Diritti Comparati, 3 May 2013.

Available at <www.diritticomparati.it/2013/05/my-entry.html\#sthash.CSIWUDeU.dpuf>

${ }^{85}$ See on the meaning and the extent of the ECB's independence: Case C-11/00 Commission v ECB [2003] ECR-7147. See also Case Annotation by O. Odudu in (2004) 41 Common Market Law Review 1073,1080 onwards.

${ }^{86}$ We should note that the BVerfG did not delve into an economic analysis examining the possibility of government bonds bought by the ECB losing value. There is a hypothesis that in the event the governments whose bonds are bought by the ECB default, the ECB may need to be recapitalised to compensate for such losses. In Gauweiler, however, the BVerfG did not engage with this issue and/or the means by which the potential losses of the ECB would be transferred into the budgets of Member
} 
be prohibited from conducting the latter policy, according to the BVerfG. At this point it should be noted that, since the scheme's announcement in February 2013, no Member State has yet applied for assistance under the OMT programme. Furthermore, the BVerfG placed the ECB's Decision under the scrutiny of German constitutional law due to the fact that it operated without any express judicial or parliamentary approval. It was in this regard that its constitutional identity review power was mentioned in so far as it can reinstate the default position that fiscal policy is only to be exercised according to the principles of representation and of distribution of powers. Equally, the Bundestag is responsible for the overall budgetary responsibility. As such, the balance of competence would only be restored once the CJEU provides assurances that the OMT Programme merely consists of a supporting mechanism for the EU economic policies and not one concerning the stability of the EMU.

The above stance with regard to budgetary autonomy or financial sovereignty is reminiscent of the Estonian Supreme Court judicial review of the European Stability Mechanism $(E S M)^{87}$ following a request from the Chancellor of Justice to declare Article 4 (4) of the Treaty establishing the ESM to be in conflict with the Constitution. Although the request was dismissed, it was stressed that 'one element of the state's sovereignty is its financial sovereignty, which contains taking decisions on budgetary matters and on the assumption of financial obligations for the state.' As such, according to the Estonian Surpeme Court, '[d]espite the strict sovereignty clause the present-day context must be considered in furnishing sovereignty. ${ }^{, 88}$

Likewise, the BVerfG has not adopted a unified and coherent approach when it comes to exercising its power to impose identity safeguards and locks upon the EU Institutions. It is consistent, however, in that its review remains purely theoretical / hypothetical and that it has on all occasions been triggered as a means of getting assurances from both the EU and the domestic institutions that the balance of competence between the EU and the Member States has not been transgressed. As discussed earlier, in the Lisbon Urteil the BVerfG even threatened the EU Institutions with unilateral action - an identity review to cover situations where the EU legislature has acted intra vires but nonetheless has impinged upon intimate areas attributed to constitutional identity.

States. Its reasoning was purely made on legal grounds - i.e. whether the OMT programme marked an important shift in the delimitation of competence to the Member States' detriment.

${ }^{87}$ Riigikohus, Judgment of 12 July 2012, Case No 3-4-1-6-12.

${ }^{88} \mathrm{Ibid}$, paras 127 and 128 respectively. 
Using a softer tone, in the Data Retention Directive implementation judgment, the BVerfG's reference to constitutional identity became a means to alert the national legislature to change their attitude towards EU law by becoming more vigilant when secondary EU law measures allow them to exercise their national discretion during the process of implementation. This is so that they may provide effective protection to constitutionally-entrenched rights. On a similar note, in Honeywell, which dealt solely with the ultra vires question vis-à-vis the constitutionality of the German labour code's reliance on the CJEU's landmark judgment in Mangold on age discrimination, ${ }^{89}$ the BVerfG made a plea to lower national courts. It rejected the constitutional complaint as unfounded and highlighted the importance of resort to the preliminary reference procedure as a method of correcting wrongful results stemming from EU legislation which may be unlawful both as a matter of national and EU law. ${ }^{90}$

In other words, the BVerfG emphasised the duty of national judges to enlighten their counterparts in Luxembourg vis-à-vis the intimacy of certain policy areas to the constitutional identity of the State. This is a constitutional requirement according to Article 101 (1) GG which stresses that no one may be removed from the jurisdiction of his lawful judge. Accordingly, the CJEU is the lawful judge to rule on the questions of EU law. Having said that, in the Counter-Terrorism Database case the BVerfG stressed that 'as part of a cooperative relationship, this decision must not be read in a way that would view it as an apparent ultra vires act or as if it endangered the protection and enforcement of the fundamental rights in the member states in a way that questioned the identity of the Basic Law's constitutional order. ${ }^{91}$

\section{iv. Identity review following a Court of Justice Decision}

The intricacies of the conceptual variations of constitutional identity as expressed by national courts give us some insight as to the level of synergy that national courts are willing to achieve with their European counterparts by singling out areas that are immune from constitutional alteration at EU level (say a Treaty revision) or by highlighting the potential, but surmountable, limit to national constitutional obligations to transpose secondary legislation. However insular and far-reaching the BVerfG's jurisprudence may be, it makes an interesting contribution to the future use of Article 4 (2) TEU. It explicitly establishes that identity encroaching acts are not only illegal under EU law but also as a matter of national law. Accordingly, the CJEU lacks the competence to interpret the provisions of the Member States' constitutions.

\footnotetext{
${ }^{89}$ Case C-144/04 Mangold v Rüdiger Helm [2005] ECR I-9981.

${ }^{90}$ Honeywell Decision of 6 July 2010, BVerfG 2 BvR 2661/06. The BVerfG provided guidance with reference to the exercise of its ultra vires review as a last resort mechanism.

${ }^{91}$ Counter-Terrorism Database Act Decision of 24 April 20131 BvR 1215/07, para 91.
} 
Such an action would be against the spirit and the letter of Article 19 TEU which sets the boundaries of its jurisdiction on the interpretation of EU law.

Following the above analysis, it is questionable whether the relationship between the domestic and European courts is dialectic. But does it really have to be? The question is twofold. First, do national judges make use of the preliminary reference system, and if they do, are they inclined to only make reference on a point of law and keep quiet about national identity? For instance shall national judges only ask their counterparts in Luxembourg about whether a particular secondary legislation in place is in tune with the powers conferred to the Institutions by the Treaty? What happens if constitutional identity features in the case at hand but is not made known to the CJEU?

To add more questions, are national judges under an obligation to mention Article 4 (2) TEU to the CJEU (and be prepared for the latter's restrictive interpretation) or keep quiet so that they reserve the right of identity review for themselves when the case returns back to them? In all cases, national courts seem to have the choice of how to frame their question to the CJEU. Hence, they need to be careful. This is so that even if identity is mentioned anyway by the CJEU during the proceedings as entrenched to the right in question, there is no competence to adjudicate on its margins given that Member States have agreed to locate the protection of national identity in their own constitutions rather than in Article 4 (2) TEU.

With the above in mind, the BVerfG requested, in Gauweiler, a preliminary ruling from the CJEU on a number of fundamental issues (including Germany's transfer of monetary sovereignty to the ECB). ${ }^{92}$ By contrast to its previous case law, in Gauweiler the BVerfG finally decided (at least in theory) to enhance its judicial dialogue with the CJEU by making use of the preliminary reference procedure in what would have otherwise been an ultra vires dispute for internal consumption. Apart from the general symbolism of judicial dialogue behind resort to the preliminary reference procedure, the Gauweiler case adds a further, and perhaps more political, dimension to the debate about possible scenarios where constitutional identity is relevant and applicable. This is the case despite the fact that constitutional identity is not a central tenet to the case.

It is worth, for instance, raising the fact that constitutional identity does not feature in the BVerfG's preliminary reference request lodged on 10 February $2014 .^{93}$ It is only

\footnotetext{
${ }^{92}$ Internationale Handelsgesellschaft (Solange I) [1974] 2 CMLR 540; Wünsche Handelsgesellschaft (Solange II) [1987] 3 CMLR 225; Brunner v European Union Treaty [1994] CMLR 57.

${ }^{93}$ Case C-62/14 Gauweiler (case pending).
} 
mentioned in the domestic proceedings - pronouncement of the judgment. ${ }^{94}$ On the one hand, therefore, the BVerfG's preliminary reference is compelling the CJEU to attach a number of conditions to the OMT program and add to the legal certainty of the EU's counter-crisis tools. On the other hand, it does not invite the CJEU to enter into a dialectic discussion over constitutional identity and its intricacies. This is because, according to the BVerfG, it is not the task of the CJEU to determine the limits of national constitutional identity.

Against the above position, in his Opinion delivered on 14 January 2015, Advocate General Cruz Villalón who stressed that the OMT program is compatible with the TFEU, engaged with the question and acknowledged the state of affairs as illustrated by the BVerfG.

...it is not only the principle of conferral (ultra vires) which is in issue in the main proceedings but also the 'constitutional identity' of the Federal Republic of Germany; that is so because of the consequences which the contested act is said to entail for the national constitutional body which is first and foremost responsible for expressing the will of the citizens. 'Ultra vires review' and 'identity review', to use the terms employed by the BVerfG itself, are said to converge in the main proceedings....

Thus, as regards specifically the 'identity review', the BVerfG expressly proposes that 'in the cooperative relationship which exists, it is for the Court of Justice to interpret the measure. On the other hand, it is for the BVerfG to determine the inviolable core of constitutional identity and to review whether the measure (as interpreted by the Court of Justice) encroaches on that core'. 95

Constitutional identity only comes into play, therefore, following a decision by the CJEU confirming the compatibility of the ECB's contested act with EU law. The BVerfG has made a distinction between identity control and ultra vires review. In its ruling on OMTs, the BVerfG mentioned that its powers cover both aspects, separately. Nevertheless, in the same ruling it also used the argument that where acts cover areas that are part of constitutional identity this could be deemed structurally significant and thus ultra vires. In the event the BVerfG declares the act of the ECB and the CJEU's interpretation ultra vires the OMT ruling would not be legally

\footnotetext{
${ }^{94}$ Federal Constitutional Court, Press release no. 9/2014 of 7 February 2014. Available at $<$ www.bundesverfassungsgericht.de/en/press/bvg14-009en.html>

${ }^{9}$ Advocate General Cruz Villalón Opinion in Case C-62/14 Peter Gauweiler and Others, 14 January 2015, nyr, paras 55-56.
} 
binding in Germany and public authorities would be constitutionally bound to disapply it.

The feasibility of such a development is, however, more easily asserted than enforced. Nonetheless, Advocate General Cruz Villalón used critical language against the BVerfGs aggressive tone and stressed that making a trend out of such a reservation of identity 'would leave the EU legal order in a subordinate position, at least in qualitative terms. ${ }^{96}$ This criticism comes at a crucial moment where the BVerfG has unilaterally modified the goalposts of its own identity review - while in the Lisbon Urteil it emphasised that the protection of constitutional identity at EU and national level went 'hand in hand', in Gauweiler it highlighted the fundamental differences and disconnection between the two modes of protection while still maintaining its preeminent role. $^{97}$

Notwithstanding the BVerfG's identity retention advances, we shall conceive the preliminary reference in Gauweiler as a call for clarification of the OMT Programme. This is especially true since there is a noticeable ennui at the political level about confronting the ECB. For instance the German Government did not seek the annulment of the OMT Programme by resorting to Article 263 TFEU. Likewise, the Bundestag has not so far criticised the OMT Programme as a set of self-contained economic measures. Neither has it made any political pronouncements about its desirability.

Considering the above, it is apparent that the approach of the BVerfG has prompted criticism of the unilateral scope of its judicial competence in allowing individuals to litigate against the Bundestag, and the government, for failing to take action against the OMT programme. ${ }^{98}$ As such, the BVerfG in its effort to protect the country's constitutional identity from external threats, can be seen to have slightly distorted the orthodoxy of separation of powers (from which each branch initially draws its identity). The BVerfG's way of protecting the concept of national constitutional identity can, therefore, lead to internal turbulence between the judicial and political branches of Member States.

\footnotetext{
${ }^{96}$ Ibid, para 60.

${ }^{97}$ See Lisbon Urteil para 240 and Gauweiler, para 29 respectively. It is worth mentioning that in the Lisbon Urteil, the second senate's composition was different to the one in Gauweiler.

${ }^{98}$ Pilakos and Anagnostaras argue that '[i]t was for the political institutions to select from a variety of possible reactions and to ascertain the need to take action at the political level. By considering the constitutional complaint admissible, the [BVerfG] allowed citizens to influence the way and the objectives of the political process beyond the current constitutional framework by granting them in essence a general right to have the laws enforced.' A. Pliakos and G. Anagnostaras, 'Blind Date Between Familiar Strangers: The German Constitutional Court Goes Luxembourg!' (2014) 15 German Law Journal 369, 371.
} 
What is more, the BVerfG may be hoist with its own petard by overburdening itself with constitutional complaints lodged by politicians disillusioned with European integration. ${ }^{99}$ In this respect, it can be argued that the impact of identity retention as unilaterally envisaged by the BVerfG may have more consequence internally (i.e. with regard to the separation of powers under the Constitution) than externally (i.e. as a means of redrawing the boundaries of EU competence without a Treaty revision). On the latter, it remains to see how far the CJEU will echo the Advocate General's Opinion and how the BVerfG will ultimately respond.

National courts have stressed in the past that after a clarification has been obtained by the CJEU and 'in exceptional circumstances' they may declare an EU measure ultra vires. ${ }^{100}$ The Danish Supreme Court has held that a domestic court may rule on the ultra vires nature of an EU measure which though upheld by the CJEU, nevertheless 'is based on an application of the Treaty which lies beyond the surrender of sovereignty according to the Danish Act of Accession.' On such a question, under Danish law, the Danish court has the final say. Of course there are more extreme responses, such as the Czech Constitutional Court's decision to declare a judgment of the CJEU ultra vires. Still, however, as it has been illustrated in the relevant commentary that the Czech Court's reaction was not 'a result of some calculated strategy' but rather a means to resolve an internal judicial conflict. ${ }^{101}$

All things said, the problem with the German approach lies in the conviction of the BVErfG judges that the distorting effect of EU secondary legislation upon Germany's constitutional identity has to be decided in Karlsruhe. Whilst this position has not been abandoned by the BVerfG, any challenge against EU acts on identity grounds remains a theoretical possibility. Having said that, identity control under Article 79 (3) GG remains a very powerful tool, as not only does it enable and justify control at national level, but it also goes beyond the requirements of Article 4 (2) TEU. This is because the BVerfG does not seem to be inclined to weigh the concept of constitutional identity against other legal interests. Perhaps this explains why the BVerfG's model of identity review has become a point of reference by, amongst other lawyers, British judges. It places considerable discretion in the hands of the Member States' authorities. A downside to this approach, however, is that, in its extreme

\footnotetext{
${ }^{99}$ See for more detail K.F. Garditz, 'Beyond Symbolism: Towards a Constitutional Actio Popularis in EU Affairs? A Commentary on the OMT Decision of the Federal Constitutional Court' (2014) 15 German Law Journal 183, 200-201.

${ }^{100}$ Denmark, judgment on Maastricht Treaty Hojesteret, Judgment of 6 April 1998 - I 361/1997. The Danish Supreme Court ruled that Danish courts must comply with judgments of the CJEU unless they have good cause to believe that an EU measure is ultra vires with regard to the Danish Constitution. In such a case, the Danish Court must refer the question to the CJEU for clarification.

${ }^{101}$ Czech Republic, Ústavni Soud, Judgment of 31 January $2012-2012 / 01 / 31-P 1$. ÚS 5/12. See case note by J. Komarek (2012) 8 (2) European Constitutional Law Review 323, especially the first two sentences in the Conclusion at 336.
} 
version, identitätkontrolle may generate a subjective, and even erratic interpretation of EU legislation.

No doubt, a state-centric interpretation of Article 4 (2) TEU would contradict the authority of the CJEU as the supreme court for determining the scope of EU law and defeat the principle of primacy of EU law. On the positive side, however, highest national courts seem reluctant to go down that lonely state-centric road. Instead, they tend to resort to the preliminary reference procedure when Article 4 (2) TEU is implicated. First and foremost, the BVerfG itself referred in Peter Gauweiler and Others the Outright Monetary Transactions Programme (OMT) to the CJEU as an example of a transgression of the European Central Bank's (ECB) mandate under the Treaty vis-à-vis Germany's budgetary autonomy (an aspect of constitutional identity protected under Article 4 (2) TEU). ${ }^{102}$ Similarly, the French Constitutional Council (CC) has declared itself not competent to consider a preliminary ruling on constitutionality when the contested provisions pertain only to the necessary results stemming from a Directive and do not violate any rule or principle inherent to France's constitutional identity. The $\mathrm{CC}$ has emphasised that 'only a court of the European Union to which a preliminary ruling has been referred may control [a] directive's conformity with the fundamental rights guaranteed by Article 6 of the Treaty of the European Union'. ${ }^{103}$

Furthermore, even if constitutional courts are reluctant to establish a dialogue with the CJEU about the contours of Article 4 (2) TEU, ordinary national courts may do so. For instance, in a recent preliminary reference, the Czech Supreme Administrative Court asked the CJEU whether favourable treatment of Czech citizens under certain circumstances defined by the Czech Constitutional Court was contrary to Article 4 (2) TEU. What is more important, however, is the Czech Supreme Administrative Court's question to the CJEU (almost as if it was a parent court on EU matters) as to whether it (the Czech Supreme Administrative Court) was bound by the legal assessment made by the Czech Constitutional Court if the latter was not on all fours with the CJEU's interpretation of the relevant provisions of EU law. ${ }^{104}$

Because the assessment of constitutional identity may vary even between national courts of the same Member State, over-reliance on national interpretations of identityretention only allows for limited awareness of the scope of Article 4 (2) TEU. It is, therefore argued that, while national judges can educate the EU lawyer about the intricacies of national constitutions, the CJEU's interpretation of Article 4 (2) TEU, as

\footnotetext{
${ }^{102}$ Ibid.

${ }^{103}$ Decision no. 2010-79 QPC of 17 December 2010, (cons 3).

${ }^{104}$ Case C-253/12 JS, Reference for a preliminary ruling from the Supreme Administrative Court of the Czech Republic, 24 May 2012 (case closed).
} 
a device for reviewing the constitutionality of EU legislation has been marginalised by the CJEU's established case law which follows a peremptory approach to the constitutional essentials of the EU. As discussed previously, this is especially the case in preliminary references where Article 4 (2) TEU is invoked by Member States as a legitimate (public policy) derogation from the substantive obligations that arise from EU membership.

\section{Conclusion}

This article explored how national identity corresponds with genuine concerns of public interest of Member States and individuals with a stake in those interests that can be construed as part of a state's national identity. We witnessed that European integration is replete with trends, movements and priorities that the use of legitimate interests corresponds with. We took stock of the recent emphasis of national identity protection in the Treaty of Lisbon as a legitimate interest and discussed the CJEU's 'integrationist' interpretation of the principle as a means of setting limits to national diversity. We also clarified that protection of national identity under Article 4 (2) TEU shall be distinguished from the protection of identity under the national constitutions.

With reference to Article 4 (2) TEU, the CJEU has recognised that the EU legal system constitutes a 'patchwork of different national regulatory styles' ${ }^{105}$ where national authorities are suitable to weigh up the balance between individual and community interests. As such, Member States should be allowed a margin of discretion to nourish the dynamic concept of constitutional identity. This is especially since 'the specific circumstances which may justify recourse to the concept of public policy may vary from one Member State to another and from one era to another.' ${ }^{106}$ However abstract this may be, it constitutes an indication that the compatibility of constitutionally entrenched values with EU law has to be ascertained by the CJEU on a case-by-case basis. The CJEU has further established that Member States do not - in the name of constitutional identity - enjoy absolute discretion to avoid their EU law obligations in order to safeguard their legitimate interests. In other words if the situation is covered by the material scope of EU law, Member States ought to exercise their competences in accordance with EU law. ${ }^{107}$ There is nothing new under the sun.

\footnotetext{
${ }^{105}$ A. Héritier, 'The Accommodation of Diversity in European Policy-Making and Its Outcomes: Regulatory Policy as a Patchwork' (1996) 3 (2) Journal of European Public Policy 149.

${ }^{106}$ Case C-208/09 Sayn-Wittgenstein, para 87.

${ }^{107}$ See Case C-446/03 Marks \& Spencer [2005] ECR I-10837; Case C-148/02 Garcia Avello [2003] ECR I-11613; Case C-192/05 Tas Hagen and Tas [2006] ECR I-10451; Case C-135/08 Rottmann [2010] ECR I-1449.
} 
This article also looked into broader trends in national identity protection in the national constitutions as articulated by national courts, acting in a protective and insular manner. In order to do so, we focused on the growing importance of constitutional identity as a unilateral national veto of prospective EU law measures and/or the unilateral disapplication of existing ones. The study of constitutional identity as a nascent notion in the process of scrutinising European integration at national level reveals a different picture compared to that portrayed by the CJEU's case law on Article 4 (2) TEU. Constitutional identity in the hands of national judges is far more than a legitimate interest - it constitutes a tool for judicial review of EU acts. Some judges tend to use this tool more extensively than others in expressing their constitutional reservations about the speed of European integration.

Although the German approach has intrigued both academics and practitioners across the EU, it appears that each national court has qualified differently the constitutional singularities that encapsulate part of its Member State's constitutional identity. The German tradition focuses on the eternity clause and the political value of the right to vote; the French on the essential characteristics of the state; while the British on a strict separation of powers, which in way is capable of reviving the old debate on the reception of EU law primacy premised on the battle between the principle of Parliamentary sovereignty and the monist conception of primacy developed by the CJEU.

The question is whether in light of the different manifestations of constitutional identity national judges will be more proactive to clarify the domestic position by engaging into a dialogue with the CJEU (by making use of Article 4 (2) TEU) and between them. Even if they prefer speaking directly to their European counterparts, there is a 'functional difficulty', according to Advocate General Cruz Villalón, of requests for preliminary rulings where Member States are not prepared to set things right. In other words, the uniformity of EU law will be shaken if Member States are $a b$ initio unwilling to consider the possibility of removing constitutional obstacles that would endanger the reception of EU law through their constitutions following a preliminary ruling by the CJEU. ${ }^{108}$

Our typology of situations where a constitutional identity review may be triggered illustrates that, in general, safeguarding the standard of protection of fundamental rights in the national constitutions is essential for the EU. As such, one could argue

\footnotetext{
${ }^{108}$ Advocate General Cruz Villalón emphasised in his Opinion in Case C-62/14 Peter Gauweiler and Others, 14 January 2015 , nyr ,that the preliminary reference procedure is aimed at effectively resolving disputes and is, therefore not to be resorted at by a national courts 'if its request already includes, intrinsically or conceptually, the possibility that it will in fact depart from the answer received. The national court should not be able to proceed in that way because Article 267 TFEU cannot be regarded as providing for such a possibility.'
} 
that despite the multiple fundamental rights sources at EU level the delayed accession to the ECHR is not very helpful for reconciling differences between the EU and its Member States. It deprives the EU from an external judicial check (the ECtHR), other than national constitutional courts. What is more, our typology also demonstrates that the preservation of democratic decision making at national level and the principle of separation of powers are entrenched in national statehood and identity. These are crucial barriers for all Member States and akin to sovereignty. Perhaps, the Commission should refrain from treating national protection of all abovementioned values which contradict the implementation of EU law as de facto breaches of EU law and, therefore, respond with a public enforcement action against Member States. Instead EU Institutions should establish a plurality of limited powers approach springing from national case studies because there are fundamental principles which have no equivalent in the EU legal order. For instance, the European Parliament released in 2011 a study on 'National Constitutional Law and European Integration' followed by another in 2014 entitled 'National Constitutional Avenues for Further EU Integration'. ${ }^{109}$ This is a welcome initiative which aims to familiarise with the variety of constitutional specificities manifest in the Member States, especially insofar as they pose substantive obstacles for further integration under EU secondary legislation.

Conversely, against national courts' unilateral claims, the CJEU may adopt an interpretation of EU obligations under Article 4 (2) TEU where respect to national identities is by default subordinate to the Article 2 TEU common values and principles forcing upon them the components of a workable EU identity, willingly adhered to by Member States. ${ }^{110}$ Seen in this light, although it can boost the protection of certain national prerogatives, the identity clause in the Treaty of Lisbon falls short of being a model for reserving or repatriating powers back to the Member States.

Having said that, a very restrictive interpretation of identity from the CJEU may backlash with an extremely insular response from the side of national judges who may decide to shut their doors to the CJEU and declare that only national courts are competent to interpret and apply norms akin to their constitutional identity. For instance, a number of Member States may follow the intra vires review set by the BVerfG to the letter. This will include Eastern and European Baltic countries such as

\footnotetext{
109 European Parliament DG for Internal Policies. Available at < http://www.europarl.europa.eu/RegData/etudes/etudes/join/2014/493046/IPOL-

JURI_ET(2014)493046_EN.pdf>

${ }^{110}$ L.W. Gormley, 'Reflections on the Architecture of the European Union after the Treaty of Amsterdam'in D. O'Keeffe and P. Twomey, Legal Issues of the Amsterdam Treaty (Oxford, Hart Publishing, 1999), 60.
} 
Estonia, Latvia and Lithuania which traditionally share a more conservative approach to European integration vis-à-vis state-specific principles that give expression to critical aspects of constitutional identity and include the possibility of subjecting EU Acts to constitutional scrutiny. ${ }^{111}$

Like the saying goes 'good fences make good neighbours': The CJEU cannot alone determine what constitutes part of the Member States' constitutional identity. This is a matter for national courts. Equally, national courts cannot decide unilaterally on the consequences for EU law of the invocation by a Member State of the identity clause of Article 4 (2) TEU. This is a matter for the CJEU. Good neighbouring and crossfertilisation of norms and jurisprudence between the two courts is therefore required to ascertain how constitutional identity situates within the spectrum of EU law. They should both acknowledge the limits of their jurisdiction and share such jurisdiction. ${ }^{112}$

The cross-over examination of national and CJEU case law in this article reveals that whilst the role of national courts is crucial in warning the CJEU about constitutional provisions which are fundamental according to their legal system and taking it onto themselves in extreme cases, the CJEU's role is equally essential in granting those national courts a margin of discretion to realise the objectives that spring out of these provisions. In some cases this may be convenient; in others it may be impractical. Indeed, 'good fences build good neighbours, but so does good open conversation over the fences." 113 A typology of situations where identity retention shall be reserved to the Member States is helpful but still the protection of national identity is bound to remain a combination of principles which often flow to each other but at times are oppositional.

\footnotetext{
${ }^{111}$ See A. Albi. 'The Central and Eastern European Constitutional Amendment Process in Light of the Post-Maastricht Conceptual Discourse: Estonia and the Baltic States (2001) 7 (3) European Public Law 433.

${ }^{112}$ P. Eeckhout, 'Human Rights and the Autonomy of EU Law: Pluralism or Integration?' (2013) 66 (1) Current Legal Problems 169. Eeckhout's theory of 'integration of laws' is applied in his article in the context of the EU-ECHR accession.

${ }^{113}$ Lord Mance, 'Destruction or Metamorphosis of the Legal Order?' World Policy Conference, Monaco, 14 December 2013. Available at <www.supremecourt.uk/docs/speech-131214.pdf>
} 